Historic, Archive Document

Do not assume content reflects current scientific knowledge, policies, or practices. 

Carpenter Seed Co.

76 University Avenue $\therefore \quad$ Provo, Utah

\section{Annual Seed Book}

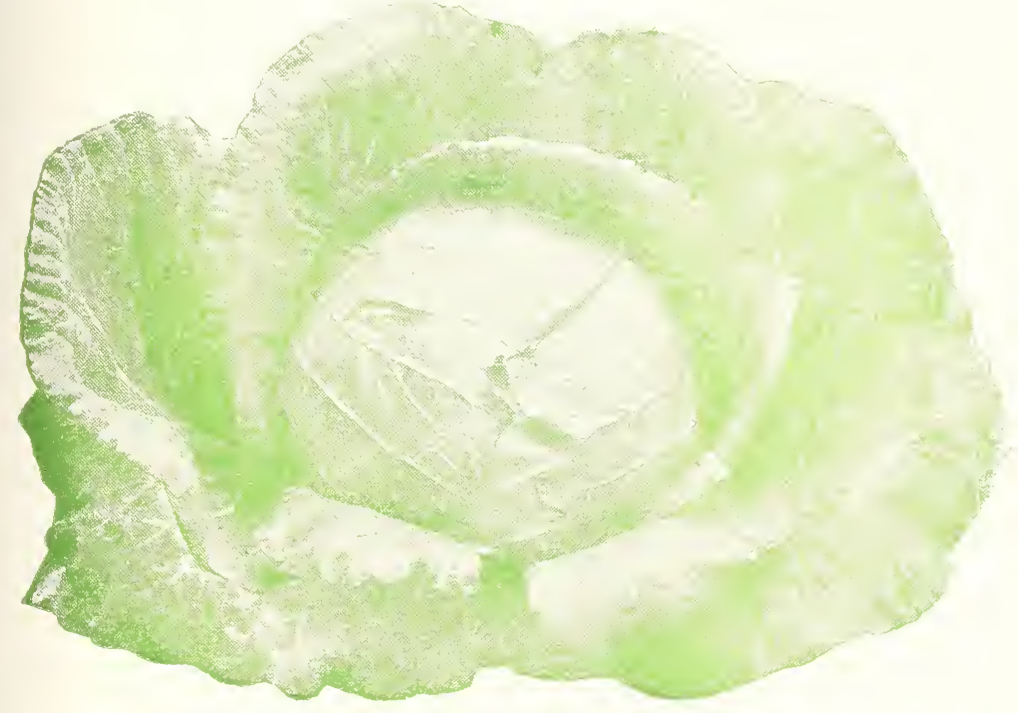

Garden, Flower and Field

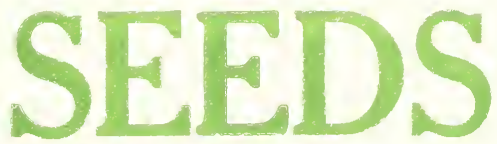

Tested Seeds Grown In High Mountain Valleys

\section{"OUR SEEDS GR OW"}




\section{TERMS AND CONDITIONS}

Weights and measures guaranteed and prices as low as those of any other reliable seed house.

We carry a large and choice stock of Grass Seeds adapted to the climate of western states. Orders always filled promptly at lowest market prices.

Terms of Sale_Cash with order. Remittances may be made at our risk by draft, money order, cash by express or in registered letters. We will take postage stamps in sums less than $\$ 1.00$, and they must be 1 and 2 cent stamps. Express money orders are always safe, and in case of loss quick adjustment can be made.

Seeds by Parcel Post Mil-We will send, postpaid, all Garden and Flower Seeds at the prices given in the following list, with the exception of heavy seeds, as Beans. Peas, Corn, Clover, Grain, Grass Seeds, and Onion Sets. If you order these by mail please be sure to add postage. Heavy seeds can be supplied cheaper by freight.

Safe Arrival Guaranteed-We guarantee the safe arrival of all seeds sent by mail or express, but request that correspondents will give us plainly their names. postoffice, county and state with order.

The importance of planting good seed is the first consideration. Remember, poor Seeds, poor crops, no matter how great the pains taken in planting or cultivation. Get only the best. We keep them, and our packages are liberally filled.

If you are a market gardner and want a large order, please send us a list of your wants for special prices.

Give us a trial order and remember that we will not be undersold on a general bill of seeds by any responsible seed house in the United States. Our seeds are new and fresh, and will grow.

Would advise ordering early while our stocks are complete. Some varities are very scarce this season.

\section{SPECIAL NOTICE}

We make a specialty of supplying Market Gardeners with the best seeds that can be produced in the United States and Europe. As we do not publish as expensive a catalogue as our Eastern competitors, and our over-head expense is much lower than those firms doing business in large cities, we are able to give you just as good seeds at a lower price than can be purchased elsewhere. Please remember that the public pays for the printing. The seeds we offer are tested under our personal supervision with the Standard Seed Tester before shipment. and every care is taken that none but reliable. fresh, and genuine good seeds are sent out. At the same time it must be distinctly understood that no reputable seed house now warrant seeds in any respect, but it must be apparent to every intelligent person that no seedman can afford to send out poor seeds, as this would destroy his business quicker than any other way. Therefore we send no goods with warranty expressed or implied in any respect, and will not be in any way responsible for the crop. If the customer does not accept the seeds on these terms and conditions. they must be returned to us at once, and the money that has been received for them will be refunded.

\section{SPECIAL OFFER \\ LARGE ASSORTMENT FOR THE GARDEN POSTPAID \$1.50}

Cost of these items bought separately $\$ 2.50$. As this assortment is packed early in the season, we cannot make any alterations or changes in the assortment.

$1 / 2$ 1b. Beans Burpee's Stringless

1 pkt. Beans Kentucky Wonder

1 oz. Beet Crosby's Egyptian

1 oz. Carrot Half Long.

1 pkt. Cantaloupe Rocky Ford.

$1 / 2$ 1b. Sweet Corn Golden Bantam.

1 pkt. Cucumber White Spine.

1 pkt. Cucumber Boston Pickling.
1 pkt. Lettuce New York.

1 pkt. Lettuce Curled Simpson.

1 oz. Parsnips Hollow Crown.

$1 / 2$ 1b. Peas Alaska.

$1 / 2$ 1b. Peas Everbearing.

1 oz. Radish Icicle.

1 oz. Radish Sparkler.

1 oz. Spinach Longstanding.

1 pkt. Watermelon-Kleckley Sweet.

You can save by ordering this lot as each item is used in any hone garden. 


\section{GENERAL DESCRIPTIVE LIST}

\section{ASPARAGUS}

CUL'IURE-Sow the seed in drills, about one inch deep, and the rows about one foot apart. Keep the soil mellow and free from weeds during the summer and in the fall or succeeding spring the plants should be set about one foot apart and the crown four inches below the surface. The beds should be narrow so as to permit of cutting to the center. Before winter cover the transplanted beds with about four inches of manure. Salt is an excellent manure for asparagus. Sow a little on the surface in the spring and it will keep down the weeds. The young tops may be cut for the table the second summer, but not very freely until the third.

\section{Postpaid.}

One ounce will sow about 50 feet of drill for transplanting and produce about 300 plants.

CONOVER CLOSSAL-A mammoth sort, frequently sending up fifteen to thirty sprouts from one to one and a half inches in diameter from a single plant, and spreading less than most sorts. Color deep green; quality good. Pkt., 5c; oz., $10 \mathrm{c} ; 1 / 4 \mathrm{lb} ., 30 \mathrm{c} ; 1 \mathrm{lb} ., 85 \mathrm{c}$.

THE PALMETNO-This variety is earlier than others, a better yielder; more even and regular in growth, and is fast becoming the favorite sort everywhere. Pkt., 5c; oz., $10 \mathrm{c} ; 1 / 4$ lb., $30 \mathrm{c} ; 1$ lb., $85 \mathrm{c}$.

\section{BEANS}

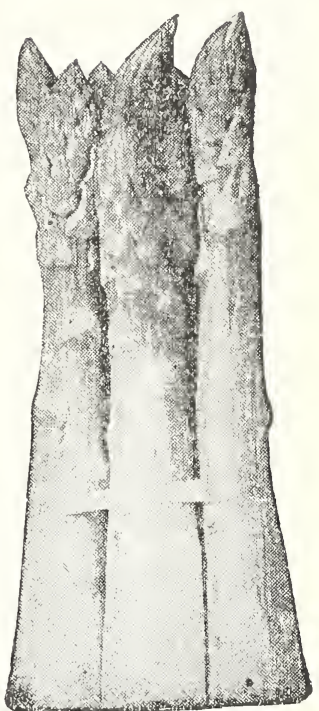

Palmetto Asparagus

WAX POD VARIETIES.

One pound will plant about 60 feet of drill, 60 to 80 pounds for one gere. Not Postpaid. See page 28 for Postage Rates.

Per pkt., 5c; 1/2 lb., 20c; 1 lb., 30; 5 lbs., $\$ 1.25$.

CUL'TURE-Do not plant them until the ground becomes dry and warm. Bush Beans may be planted about 2 inches deep in drills from 24 to 30 inches apart accord. ing to variety and soil, placing the seed 3 inches apart or 4 seeds in hills 24 inches apart each way; 2 pounds per 100 foot drill.

DWARF BLACK WAX A very superior snap-short wax bean; ripening among the first earliest, and having the best characteristics. Pods round, yellowish white, fine flavor.

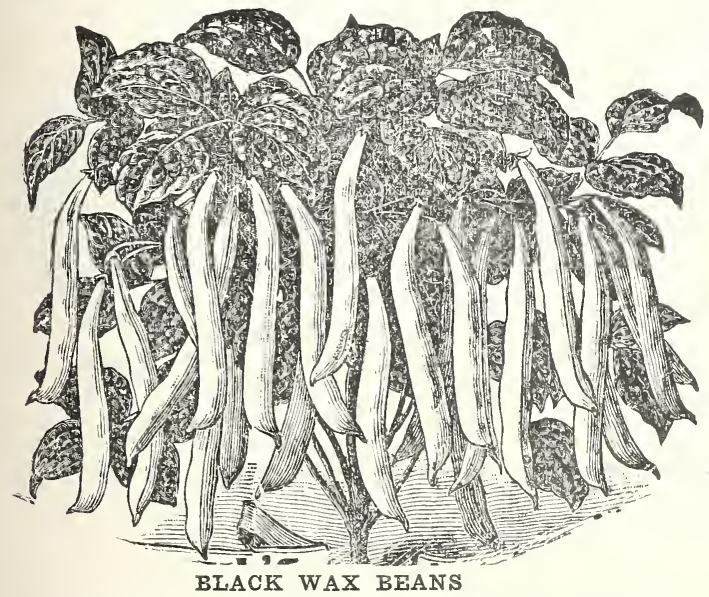

DAVIS WHITE WAX-Im. mensely productive. bearing large, handsome, straight pods five to six inches in length. The pods are almost solid flesh and with decided strings when of good size, one of the best for canners, as it does not discolor. It is also a good shipper. Tho dry seed, being white and of medium size, is desirable also for winter market as a shell bean.

IMPROVED GOLDEN WAXPossesses all the good points of the old Golden Wax, but is larger in pod and much more prolific; of tender, melting flavor at all times of its growth.

REFUGEE OR ONE THOUSAND TO ONE-Pods about 5 inches long. Fine for late planting, especially for canning being almost stringless. 


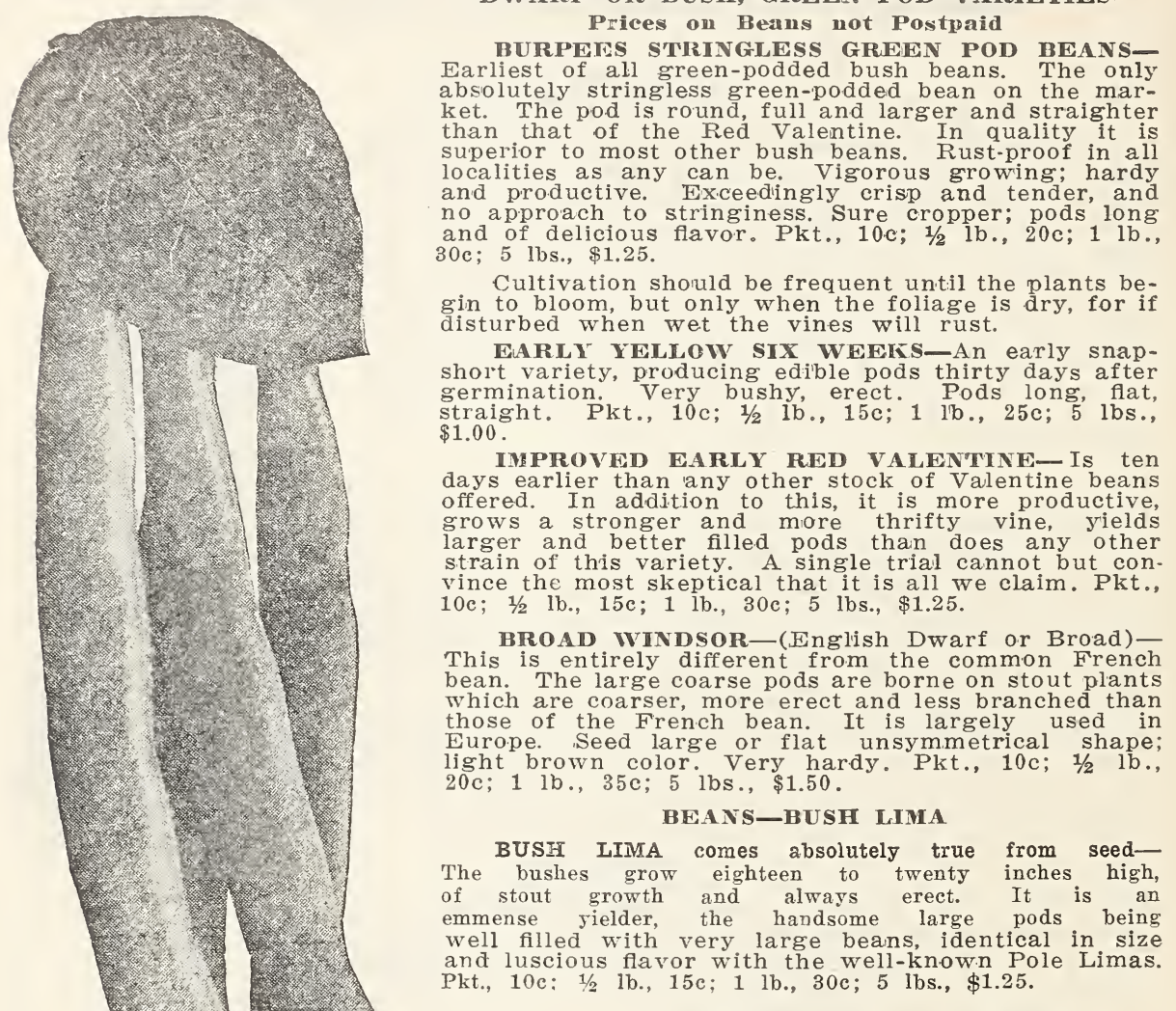

\section{BEANS-POLE OR CLIMBING}

LAZY WIFE- Immensely popular everywhere. It is exceedingly productive and easily gathered. Probably this is why it comes by its very discourteous name. It is an excellent bean. Pkt., 10c; $1 / 2$ 1b., 20c; 1 lb., $30 \mathrm{c} ; 5$ lbs., $\$ 1.25$.

KENTUCKY WONDER-Vine vigorous, climbing well and very productive bearing its pods in large clusters; blossoms white; pods green, very long, often reaching nine or ten inches, nearly round when young and very crisp. Pkt. 10c; $1 / 2$ lb., 20c; 1 lb., 30c; 5 lbs., $\$ 1.25$.

SCARLET RUNNER Or FLOTERING B EA N-A great favorite; both ornamental and useful; height ten feet, presenting dazziing scarlet flowers from July to October. Used both as a string bean and shelled. Pkt., 5c; 1/2 1b., 20c; 1 ib., $35 \mathrm{c}$; 5 lbs., \$1.25. 


\section{BROCCOLI}

CULTURE-Sow early sorts as soon as the ground can be worked in the spring, in shallow drills, drawn three or four inches apart. Plant out two feet apart each way when the plants are about four inches high. Cultivate the same as cabbage, in rich soil. Use the same remedy for insect attacks as are recommended for cabbage. They are excellent and deserve much wider culture than is usual in this country.

Nearly allied to the Cauliflower, but more hardy. It succeeds best in a moist and rather cold atmosphere.

LARGE WHITE MAMMOTH-A valuable variety, with very large, firm heads. Pkt., $5 \mathrm{c} ;$ oz., $25 \mathrm{c} ; 1 / 4$ lb. $75 \mathrm{c}$.

\section{BEETS}

Postpaid.

GARDEN BEETS FOR TABLE USE.

One ounce will sow 60 feet of drill; six to eight pounds for one acre in drills. Ready for table use in 40 to 60 days.

Pkt., 5e; oz., 10e; $1 / 4$ 1b., 25e; 1 lb., 75e.

CULTURE-Sow as early in the spring as the ground can be worked and every two weeks after for a succession up to the first week of July. For general crop sow about the middle of May. The soil should be light sandy loam, well enriched with stable manure and plowed and harrowed until very fine. Sow in drills one foot to fifteen inches apart, and when well up, thin to from four to six inches. The young beets pulled out of the rows are excellent used as greens.

DETROIT DARK RED-The earliest and best turnip shape beet in the market, being more globular than its parent, the Early Egyptian. Market gardeners should take no other variety for early market. Supply is limited this season.

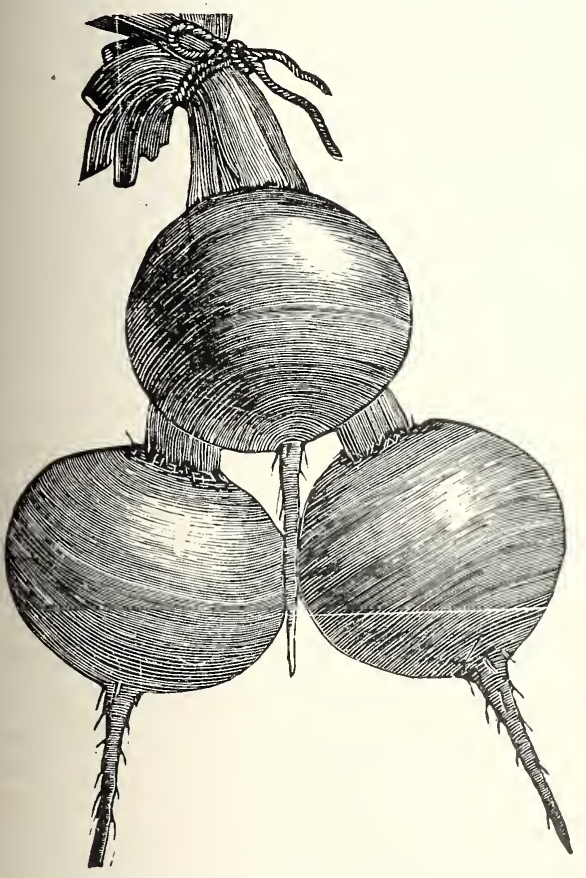

EARLY BLOOD TURNIP BEETS

\section{CROSRY - EXTRA EARLY EGYPTIAN} -A very popular eariy turnip-shape variety. Has small tops and grows quickly. The flesh is in alternate rings of white and deep red.

EARLY RLOOD RED TURNIP-Here we have the old stand-by, the turnip beet with its dark red color, well known to so many homesteads. It is useless to occupy space in describing it, suffice to say, it is the best variety for family use.

\section{STOCK BEETS}

Nothing better for cattle, hogs and sheep. Oz., 5c; 1/2-1b., 25e; 1-1b·, 45e. Postpaid.

CULTURE-A.s all Mangels require a deep soil in order to grow well, plow and sub-soil at least a foot to 18 inches and apply plenty rich stable manure. Sow in May or June, in rows eighteen inches to two feet apart, and thin to eighteen inches in rows.

GOLDEN TANKARD MANGEL-Shape, cylindrical; color, deep, rich yellow; flesh yellow, circled with white. Unequaled for feeding stock. It is an enormous cropper.

MAMMOTH LONG RED-A particularly fine stock of Mangel The roots attain enormous size, smooth and regular in

shape. It grows well above ground and is easily pulled. The best variety for deep, loose soil. 
GIANT HALF SUGAR-This is a cross between Mangel Wurtzel and Sugar Beet. Rich in sugar and yields equal to the Mangel, making it a very valuable acquisition for stock feeding. Do not fail to include this in your order.

NEWV MANGEL BEET SLUDSTRUP-It is the largest producer of any of the mangels, often yield. ing 60 tons to the acre. It grows largely above the ground and is very easy to harvest. Color, a golden yellow. In nutrition it surpasses a.ll others and is the best keeper on the list. TRY IT.

TO THE STOCK GROWER:

We wish to call special atten. tion to stock beets and carrots as a feed for cattle, horses, hogs, sheep, etc.

Mangel or stock beets a n d sugar beets yield from 30 to 50 tons per acre, and we consider a ton of them as valuable for feed as a ton of hay, and with hay at the price which it is bringing now, it is plain to be seen that there is money in raising these roots for stock. With a little extra work they can be kept all winter and there is nothing that produces as much milk as beets and carrotscarrots add that splendid golden color to butter which helps bring the price.

We would advise extensive planting. The best ones are GiantHalf Sugar, Large Red Mangel and Golden Tankard b e t s; Yellow Australian, White Belgian, Long Orange and Voges carrots.

Do not fail to include these in your order for seeds for spring planting. oz., 5c; $1 / 21 \mathrm{~b} ., 25 \mathrm{c} ; 1 \mathrm{lb}$. ,
$45 \mathrm{c}$; postpaid.

\section{CABBAGE}

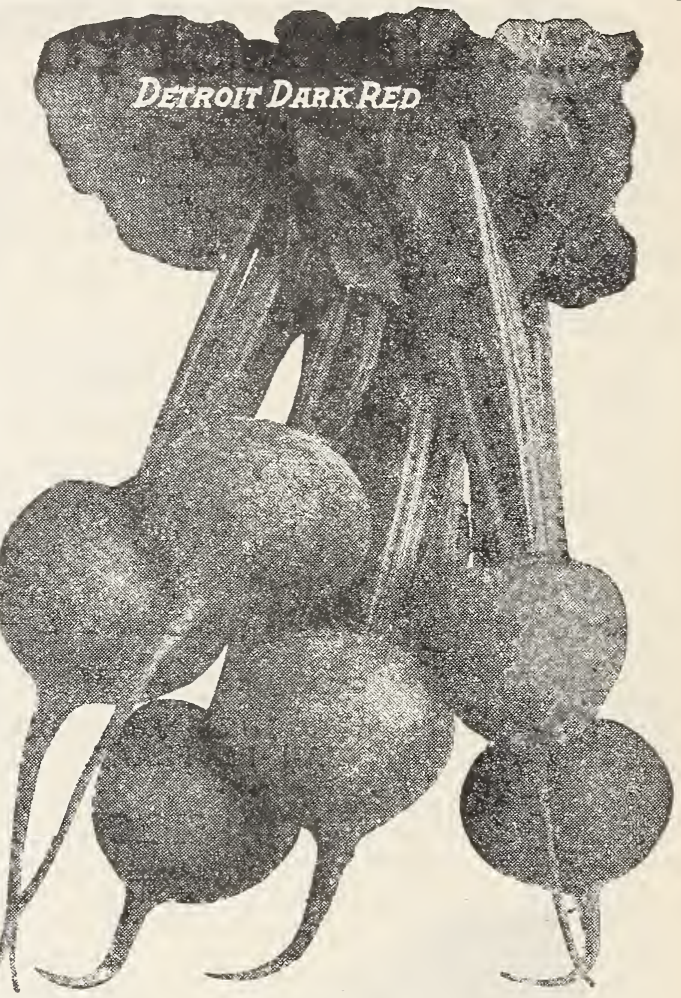

Postpaid.

One oz of seed will produce 1,500 plants. Pkt., 5c; oz., 20c; 1/4-1b., 50c; 11 b., \$1.75. Ready for use in 75 to 120 days.

CULTURE-Soil for Cabbage should be a rich and heavy loam, with good drainage. Start seed for early varieties in a hot bed or in boxes in the house. In a month the plants will be in condition to transplant, taking care, in planting, to set the young plants down to the first leaves. Transplant in spring as soon as the ground can be worked, setting the plants two feet apart one way and from twelve to fifteen inches the other, according to the variety. For late or winter crops the seed is sown in May, and the plants set out in the second week of July. In this case they are set in rows 2 by 3 feet, so as to work them with a horse and cultivator. To destroy the green worm that is so destructive to the leaves and heads of Cabbage and Cauliflower, an

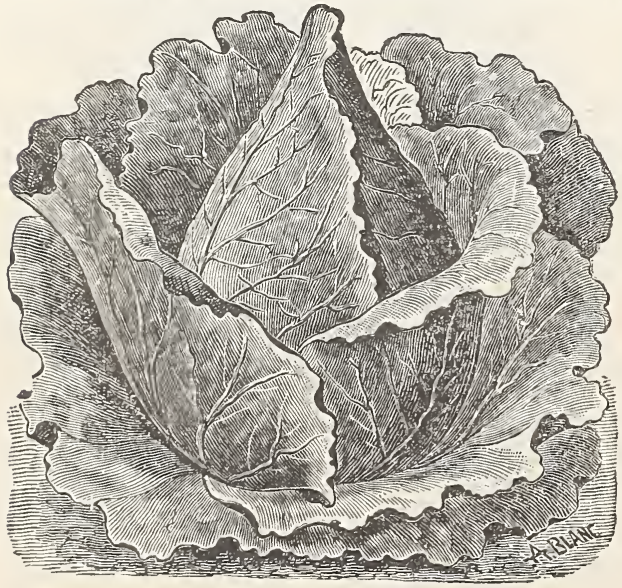

Jersey Wakefield. experienced grower says: "Take one ounce of saltpetre and dissolve it in twelve quarts of water, then take a short handled whisk broom, dip it in the solution and sprinkle the plants well. One application is sufficient unless the stuff is washed off by heavy rains. The liquid being perfectly clear, never colors the cauliflower or cabbage heads. To prevent the turnip flea from attacking the young plants, sift fine air-slacked lime or tobacco dust over them as soon as they appear above the ground. Use Arsenate of Lead for cabbage worms, Black Leaf 40 for louse or aphis. 
WE CARRY THE FINES'T S'TRAINS OF DENMARK GROWN CABBAGE SEED, MARKET GAIDNERS CAN DEPEND ON PIANTS FROM OUR SEED HEADING.

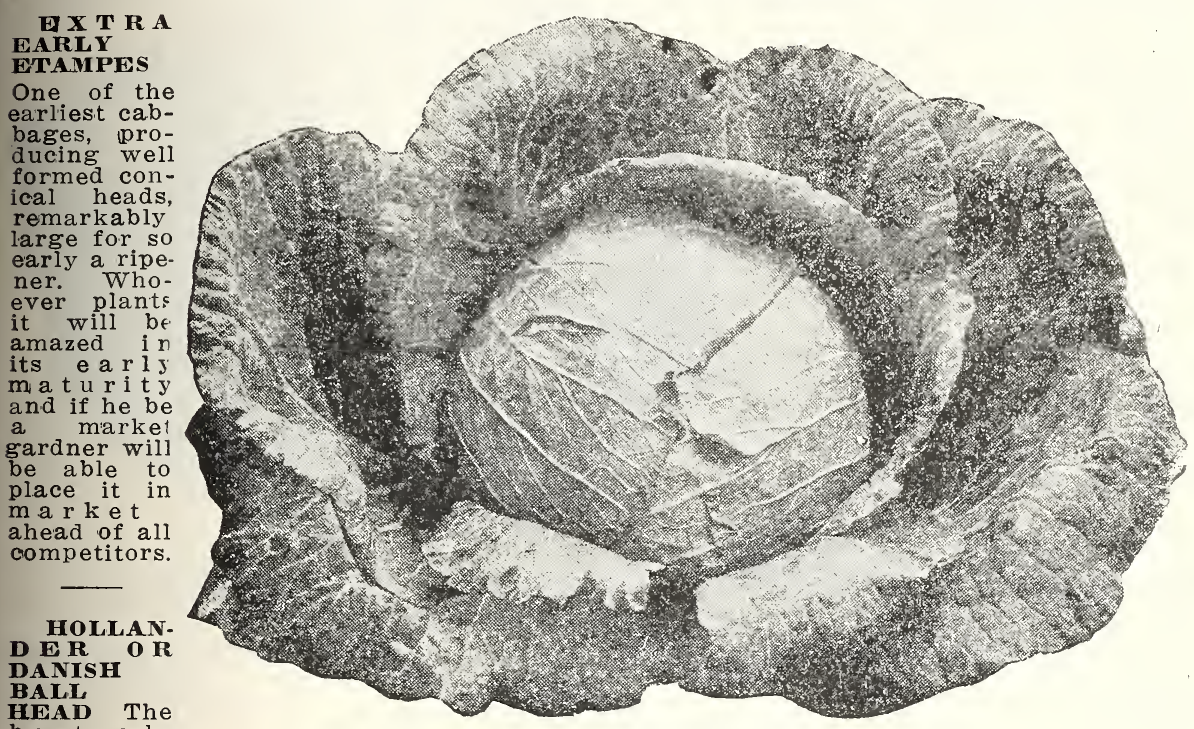

best cab-

ba g: e to

store during

the winter, and is in large demand everywhere at profitable prices during the spring months. Our stock is the very best type of this, the best of all late cabbages. Originated in Denmark and grown and selected for more than fifty years by Danish gardenérs, many thousands of tons being imporied into this country annually. Heads are hard, round, of good marketable size, fine-grained and long keeper. Grown in Denmark.

CA BBAGE, IMPROVED AMAGEF, "DANISH ROUNDHEAD"-Short stemmed, two weeks earlier than Ball Head, head round, large, good for winter keeping. Is especially recommended for high and light soil.

COPENHAGEN MARKE'T-This is the finest large round-headed medium early cabbage; the heads maturing all at the same time. They average about 10 pounds each; are very solid with small core and fine quality. Sowed in March they are ready for market the latter part of August, in our trial ground, and are about as early as Charleston Wakefield, but will give a much heavier yield per acre. It is short stemmed with small saucer-shaped light green leaves, always tightly folded, and can, therefore, be planted ciuse. Price of above three varieties,

EARLIEST OF ALL-This is a new type developed in Denmark last season. It is very early, and has a round head. Very firm and solid. Has been itested out here and does remarkably well. Good variety, for market gardeners. O\%., 25c; 1/4 1b., 75c; $1 \mathrm{~b} ., \$ 2.00$.

EARLY WINNINGSTAD'T-A well known and very popular early variety, in season very close to the Wakefield; heads large, decidedly conical; leaves bright glossy green; heads solid and hard, even in summer. This is a very sure-'heading variety, valuable not only for early use but also for winter cabbage.

TRUE JERSEY WAKEFIELD-This is an admirable sort, and fully sustains all we have heretofore said in its favor as a variety suited to the family and market garden. The heads begin to mature in the latter end of June to the first of July, and may be cut in succession for several weeks. Our seed is true Long Island grown.

EARLY DWARF FLAT DUTCH-Has succeeded admirably on account of its ability to resist heat; it never flaws under the severest sun and it produces very fine, large heads after the earliest sorts have disappeared. We recommend it highly.

ALL SEASONS-A new Drumhead Cabbage as early and every way as good as Early Summer, but yielding heads from a third to a half as large again. This new cabbage, while it matures a day or two later in the spring, when planted in July, matures a day or two earlier than Early Summer in the fall, so that it will average as early while the solid heads are from a third to a half as large again. As a rule, our earliest cabbages are only good as early cabbage, being too small for late, or too small and too thin to be kept over winter; but the head of this new cabbage being large and also thick through make it a most excellent variety, either for extreme early or fall or spring market. 
PREMIUM LATE FLAT DUTCH - As a variety for winter market it has no superior, and is more extensively grown than any other. Heads large, bluishgreen, round, solid, broad and flat on top, and often tinted with redish-brown after being touched with frost; they open white and crisp, are tender and well flavored. It is a fall and winter variety, and one of the very best to keep. With good cultivation, on moist, rich ground, ninetyfive in a hundred will head up hard and fine. Decidedly the best late variety for cultivation in our state.

GLORY OF ENKHUIZEN-This second early variety is very sure heading and of excellent quality. The plants or of rigorous growth, with large, rather spreading outer leaves which are noticeably curved and frilled. The heads are globular or very nearly round, very solid and of large size for so early a variety.

LATE LARGE DRUMHEAD -This is also a very large fall and winter variety. It is similar in most respects to the Premium

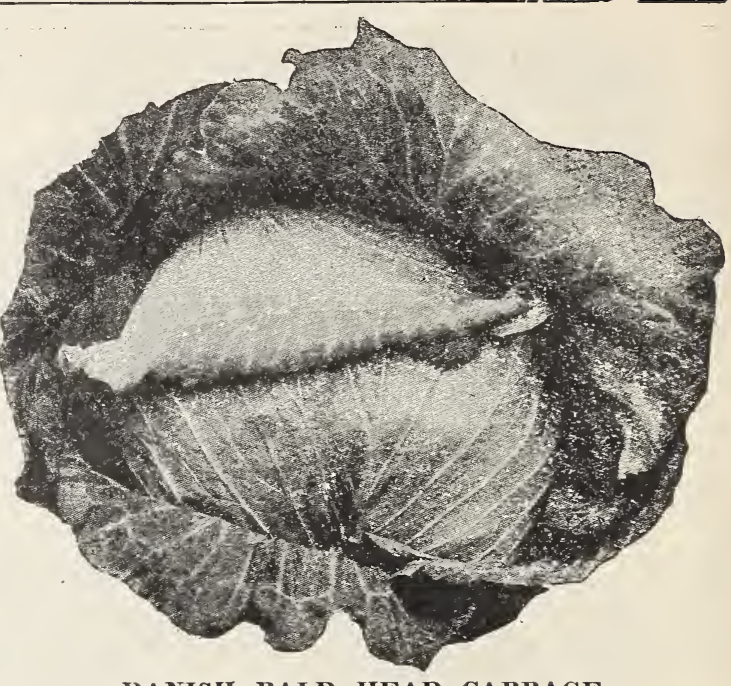

DANISH BALD HEAD CABBAGE

Flat Dutch, but the heads are more rounded on top; it is also generally longer in size.

SESSIONS-This has proved to be a most excellent acclimated second early variety. It is low on the stump, heads solid and compact, weighing from ten to fifteen pounds each, and is sure to head. From seed sown in March good sized heads can be marketed in June. A very valuable variety.

DRUMHEAD SAVOY-The finest flavored of all the cabbage family; large and solid; used extensively in the markets of Europe, but not so well known in this country.

MAMMOTH ROCK RED-This is the best, largest and surest heading red cabbage ever introduced. Heads deep red to the center, and will frequently average twelve inches. A sure cropper and in every way a first-class sort. Price of above varieties: pkt., 5c; oz., 20c; 1/4 lb., 50c; 1 lb., \$1.75. Postpaid.

\section{CAULIFLOWER}

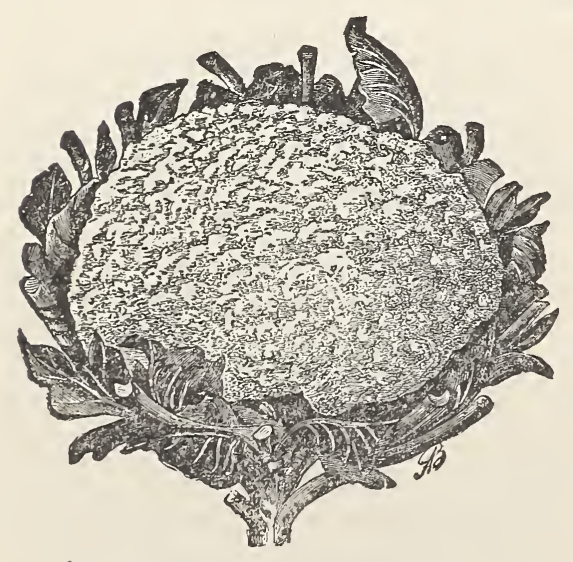

DANISH SNOWVALL.
Postpaid.

One ounce will produce 1,500 to 2,000 plants.

CULTURE-This is the same as for cabbage, except that extra manure and plenty of water will pay upon this. If the soil be dry, water frequently, and if the plants could have a heavy mulch of hay or straw, it would keep the soii moist and the plants would not suffer from drouth. The early kinds should be strong enough to plant out not later than the middle of April, the ate kinds may be planted out same time as for cabbage. To destroy the Cauliflower maggot, it is recommended to take one ounce of sulphate of potassium and dissolve it in one gallon of water. Heat the liquid to about 100 degrees, take a large spoon, or something that will hold the 100 th part of a gallon, and pour the liquid against the stalk of the plant just above the ground.

DANISH SNOWBALL - Exceedingly early and hardy and a very sure header. Outer leaves are erect, while the inner ones lap well over the head, protecting from the sun. It is a good late sort. Our seed is of the very best strain. Pkt., $10 \mathrm{c} ; 1$ oz., $\$ 1.50$; $1 / 4-1 b ., \$ 5.00$. Grown in Denmark. 
EXTRA EARLY DWARF ERFURT-(Selected.) This is the choicest selected strain of the popular Erfurt type, and is remarkable for its extreme reliability in heading. Plants very dwarf, with solid pure white heads of superior quality. Per pkt., $10 \mathrm{c}$; 1 oz., $\$ 1.25 ; 1 / 4-1 \mathrm{~b} ., \$ 4.00$.

DANISH GIAN'T OR DRY WEATHER-Large leaved and large flowering with pure white compact heads. For open ground and forcing. Two weeks later than Snow Ball, when planted at same time. Very resisting against unfavorable seasons and dry weather. Grown in Denmark. Per pkt., $10 \mathrm{c} ; 1 / 4$ oz., $50 \mathrm{c} ; \mathrm{oz} ., \$ 1.50 ; 1 / 41 \mathrm{~b} ., \$ 5.00$.

EARLY PARIS-An excellent French variety, and the popular early sort in the Paris markets. Being so early, it must always be a favorite. Per pkt., 10c; 1/4-oz., 30c; oz., $90 \mathrm{c}$. $1 / 41 \mathrm{~b} ., \$ 2.25$.

\section{BRUSSELS SPROUTS}

Postpaid.

CULTURE-Sow in May in the same manner as Cauliflower and transplant in July, one foot apart, in the rows which should be one and one-half feet apart. In gardens, both large and small, Brussels Sprouts are, without exception, the very best winter vegetable that can be grown. The real sprout is not much larger than a marble, and as firm and hard almost as the stalk itself. These are the sorts which cooks prefer. They strip off the outer covering, cook them whole, and serve them up artistically in that fashion. When cooked through and no more, such Sprouts melt in the mouth like the tenderest Cauliflower, and are equally as good.

This is one of the best vegetables for winter use, producing from the axils of the leaves an abundance of sprouts resembling small cabbages; an excellent, mild flavor. It is a delicacy much esteemed in Europe. Sow in seed-bed middle of spring and transplant and manage as winter cabbage.

DWARF IMPROVED - A variety producing compact sprouts of excellent quality. Pkt., 5c: oz., 15c. 1/4-1b., 30c: 1 lb., $\$ 1.00$

\section{CARROTS}

\section{Postpaid.}

One ounce will sow 150 feet of drill. Three pounds for one acre.

Per pkt., 5e; or., 10e; $1 / 4$ lb., 25e; 1 1b., 80c.

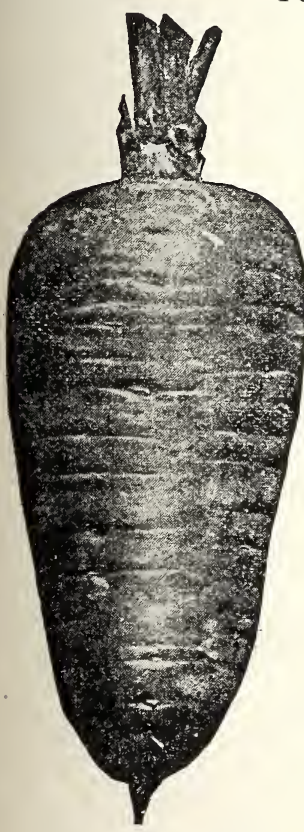

DANVER'S HALF LONG CARRO'T

CULTURE-Any garden soil will grow carrots. For early crops sow as early in the spring as possible and in rows eighteen inches to two feet apart. Cover not more than $1 / 2$ inch deep. When the plants are about three or four inches high thin out to two inches apart for the small early varieties and four inches apart for the late ones. Give them plenty of room. Keep them thoroughly hoed.

A packet will plant about 20 feet; an ounce, 150 feet: and three pounds, an acre.

The late crops should be dug in the autumn and stored like Turnips and other root crops.

OX-HEART Or GUERANDE-This French carrot is one of the most valuable of all recent introductions, either for familp use or markets. It is an intermediate between the Half Long and Horn varieties, attaining a diameter of three or four inches at the neck and of most beautiful shape and rich orange color. It is of extra fine quality and very productive.

DINVIR'S HAIF LONG ORANGE-A decided acquisition of the Half Long type, admirable in color, fixed in habit, a wonderful producer, the best of all for the stock-breeder and valuable to the market gardener. With this variety the planter secures the largest return to the acre with the least difficulty of harvesting.

LONG ORANGE-The old stand-by, both for table use and for stock feeding, for late summer and winter. Fed to milch cows, it increases flow of rich milk and imparts to the butter in winter a fresh flavor and golden color.

CHANTLNAY - This variety is a very productive one. It has an extra large shoulder, is easily dug, and is desirable in all respects. It is a stump rooted sort, very smooth, fine in texture and of a beautiful, rich orange color. For table use it is by many, considered to be the best of all, both on account of shape and quality. The flesh, when cooked is very tender.

LARGE WHITE BELGIAN-Grows one-third out of the ground. Root pure white, green above ground with small top. It will grow to a very large size, on light, rich soil, and is very easily gathered. Flesh rather coarse, is raised exclusively for stock. 


\section{STOCK CARROT}

\section{Postpaid.}

Price, pkt., 5e; oz., 10c; 1/4 1b., 25e; 1-1b., 60 .

NEW LARGE YELLOW OR GIANT AUSTRALIA. CARROT-In this new competitor among carrots we have a variety which excells all records of even the large Belgian sorts, hitherto the champion among car rots. In size, yield, weight and quality, it is ahead of them all. It is reported that a single specimen has attained a weight of 15 lbs., and an average yield of 50 tons per acre. "This variety originated at the Australian Experiment Station at Sidney. It is of a beautiful yellow color, which gives to the butter that rich, golden hue we all admire. Its enormous yielding characteristics save one-half the cost of harvesting and reduces the cost of seed to a minimum, as it takes only two pounds to seed an acre.

MASTODIAN-A new carrot from Russia. Gigantic size and wonderful keeping qualities. Yields 40 to 50 tons to the acre and is very hardy. Is a splendid feed for stock and one of the most profitable to plant.

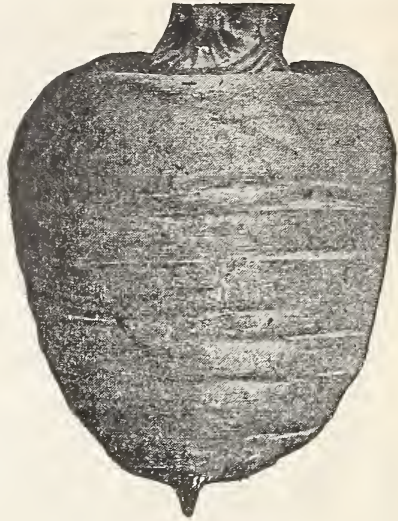

OX-HEART CARROT

\section{POPCORN}

Not Postpaid. See page 38 for Postage Rates.

Per $1 / 4-1 b ., 5 c ; 1-1 b ., 15 c$.

WHITE PEARL-A very handsome variety; kernels round; color, white, very prolific. WHITE RICE-The best for home or market. Grains pointed.

\section{SWEET CORN}

Per pkt., 5̌; 1/2-1b., 15̌c; per 1b., 25c; 10-1bs., \$2.25. See page 38 for postage rates.

CULTURE-Plant as soon as the ground becomes warm in the spring, in hills about three feet apart; give thorough cultivation. Our sweet corn is carefully grown and selected, only the choicest, most perfect ears being selected for seed. It is far superior to ordinary stock.

MAMMOTH WHITE CORY-The largest and best extra early sweet corn. The stalks are no larger than those of the White Cob Cory, but each stalk furnishes two or more large, fine-shaped ears, which are fit for use before those of any other sort. The -ars are twelve-rowed, very symetrical and handsome, with no opening between the rows at the base. The grain is large, broad, very white and of remarkably good quality or such an early sort.

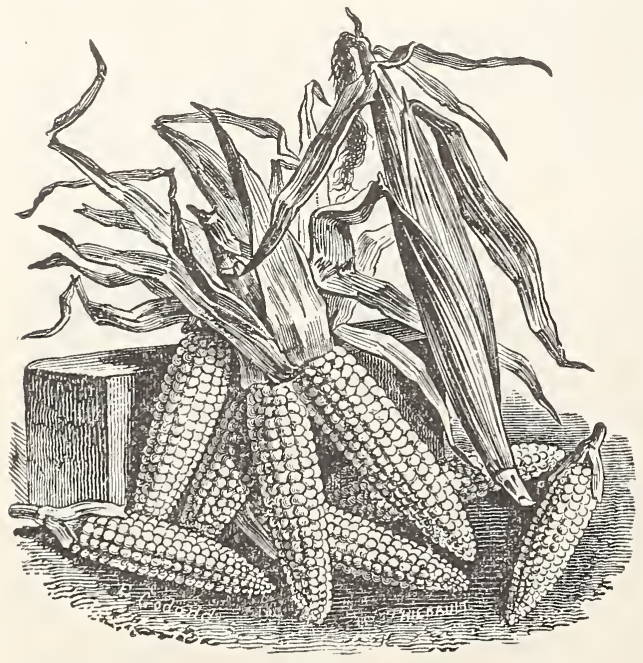

GOLDEN BANTONI CORN

COUNTRY GENTLEMAN-The ears are not only of good size, but are pro. duced in great abundance, frequently bearing four good ears, while the average is three to a stalk. The cob is very small, giving great depth to the kernels, which are of pearly whiteness. But the great merit of the Country Gentleman corn is its delicious quality It is, without doubt, the sweetest and most tender of all sweet corn, and at the same time with ears of good size.

STOWFIL'S EVERGREEN-This va riety is more largely planted than any other, being the general favorite with canners and market gardeners for late use. It is very productive, the ears are of a large size, grains deep, exceptionally tender and sugary; and remains for a long time in an edible condition. This veriety with one or two of the early varieties for a succession, is necessary to every garden.

\section{NEW GOLDEN BANTAM-T H} EARLIEST OF ALL SWEET CORNThis new sweet Corn is described as the cenderest, sweetest and best evergreen Sweet Corn in existence. Its attractive yellow color being another good feature added to its many good qualities, makes it an easy seller on the market. The stalks are vigorous and strong, grow about 4 to 6 feet high and produce three to four good ears which has been developed from 8 rows to 12 rows and over on each ear. On account of its firm texture it ean be planted earlier than any other variety of Sweet Corn. Do not fail to try it. 


\section{SELECTED FIELD CORN SEED}

\section{Not Postpaid. See page 38 for Postage Rates.}

Price per lb., 10e; 10 lbs. 90c; 50 lbs., \$3.00; 100 lbs. $\$ 6.00$.

Field Corn prices are subject to change without notice The last five varieties mentioned are well adapted for silos. The Pride of the North is very early and does well in altitudes above 5000 feet. The others are all good below 5000 feet. Remember we make a specialty of silo corn

\section{FLINT SORTS.}

AUSTRALIAN WHITE FLINT-The earliest and surest variety we have for the arid lands of the West. It will actually endure more drouth and cold than any other variety known. Grows to a height of six to ten feet, ears varing from eight to twelve inches long, usually eight or ten-rowed, one and two ears on a stalk.

\section{DEN'T SOR'TS.}

KING OF THE EARLIES-(85 days.) Minnesota grown. Stalks grow six to seven feet high, ears from seven to nine inches long, very deep, soft grain, and small red cob, 12 to 16-rowed. Valuable for the extreme north.

UTAH YELLOW DEN'T-An early Dent variety, ripening with the Flint varieties, and can be grown in almost any locality. Stalks large, with broad leaves, ears eight to ten inches, sixteen rowed, grain yellow, making a good quality of meal.

PRIDE OF THE NOR'TH-( 80 days. $)$ This variety has smaller ears than late kinds, but is valuable to grow, as it matures earlier. Planted as late as July 4th, it has fully matured by October 1st. The ears have from fourteen to sixteen rows, grown eight to ten inches in length, slightly tapering. The kernels are closely set together on the cob, of a light orange color. The stalks usually grow six to eight feet in height, producing one or two good ears. Our seed of this variety has been grown for us with special care, from the original stock.

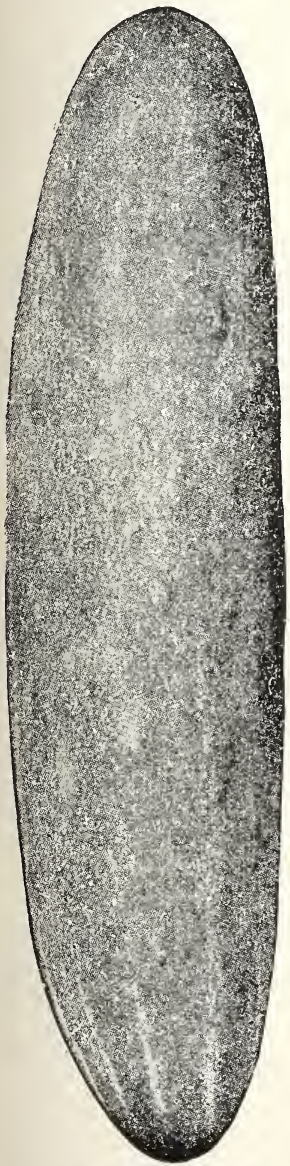

Long White Spine Cucumbers

IMPROVED LEAMING-(90 days). This is one of the earliest large yellow Dent corns in cultivation, ripening in 90 to 100 days from planting. It is extra early and not a hard flinty corn. The ears are large and handsome with deep, large grains; orange yellow color and red cob. Stalks medium size, tapering gradually, producing two good ears each.

IOWA GOLD MNE CORN-(90 days). A medium early large, yellow Dent that is valuable for parts of Iowa and the Middle States, The grain is deep, a golden yellow color, ears of good size. Cobs small. One of the best silo Corns.

IOWA SULVER MINE-( 90 days $)$. The stalks grow to a height of seven or eight feet and set the ears about three and a half to four feet from he ground. "The ears measure from ten to twelve inches in length and often weigh one and a half pounds. They are very uniform in size and shape, with sixteen to twenty straight rows of deep pure white kernels on a small white cob. It is the heaviest yielder we know, having yielded over 200 bushels to the acre. Seventy pounds of ears will make sixty-two pounds of corn. It is entirely distinct and will give satisfaction.

\section{CUCUMBER}

One ounce will plant gbout 50 hills. Two pounds, one acre. Per pkt., 5c; oz., 10e; 1/4-1b., 25e; 1-1b., 90c. Postpaid

CULTURF-Cucumbers are planted in hills which, for best results, should be made as follows: Dig holes about a foot in diameter. Fill these with thoroughly rotted manure or compost, tramp down tightly and soak with water. On top of this build a mound about 4 inches high of fine soil. These hills can be made at any time but the seeds should not be planted until the weather and soil have become quite warm.

Plant about a dozen seeds in the top of each hill. Cover them about a half inch and press the soil down firmly.

When the plants put forth the third pair of leaves thin out to the four strongest plants to the hill. The hills should be about three feet apart. Keep the soil loose and free of weeds, but after the plants have started to cover the ground do not move them.

One ounce will plant 50 hills, two pounds will plant an acre. 


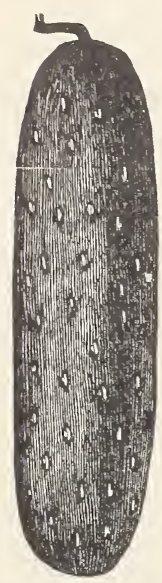

Long Green

EARLY CLUSTER-A very popular early cucumber producing its fruit in clusters near the root of the plant. Its usual length is about five inches; skin prickly; flesh white, seedy, tender and well flavored.

BOSTON PICKLING-A distinct variety which has obtained a great degree of popularity in Boston market as a pickle. Medium long; a great producer.

COOL AND CRISP-The peculiar feature of this variety is the knobs or protuberances upon which the spines are placed are very prominent, giving an attractive appearance. "This variety is the earliest and most prolific of all pickling cucumbers; will become a standard sort. Dark green, almost black.

FARLY WHITE SPINE-Vines vigorous, fruiting early and abundantly; fruit uniformly straight and handsome, dark green, with a few white spines; flesh tender and of excellent flavor. In this country this variety is used more, perhaps than any other for foreing under glass.

EXTRA LONG WHITE SPINE-A selected strain of the White Spine. Is very uniform in size and exceedingly early, at same time makes long: growth-ten to twelve inches. The variety for forcing and early market.

IMPROVED LONG GREEN-Unquestionably this is the most popular general purpose cucumber in the West. When matured is nine to twelve inches long, very solid and crisp; retains its dark green color until nearly ripe. One of the best for small pickling if picked promptly.

JAPANESE CLIMBING-This novelty is entirely distinct from all other cucumbers, climbing on poles, trellises, fences, etc., like a gourd. The vines are vigorous and healthy, and produce large numbers of fine, large smooth tucumbers of excellent quality. They are especially fine for slicing. Per pkt., 5c; oz., 10c; $1 / 41 \mathrm{b.}, 25 \mathrm{c} ; 1 \mathrm{lb.}, 90 \mathrm{c}$. Postpaid.

\section{CHICORY}

\section{Postpaid}

The roots dried, cut in thin slices, roasted, and ground are used largely as a substitute for coffee. The leaves make an excellent salad for early spring, large rooted or coffee. Per pkt., 10e; oz., 30; 1/4-1b., 75c; 1 lb.,\$250.

\section{CORN SALAD}

\section{Postpaid}

CULTURE-Sow during August or early in September, in drills a quarter of an Inch deep and six inches apart. If the weather is dry when the seed is sown, tread it in slightly to insure germination. Keep down weeds with hoe. Just before winter cover thinly with straw or leaves.

BROAD LEAVED-Used as a small salad throughout the winter and spring. Sow thickly in drills, cover slightly first of autumn, and sprinkle with straw on the approach of severe weather, or sow in a cold frame, covered in winter as may be convenient-thus it is accessible, even when deep snow prevails. Pkt., 5c; oz., 10c; $1 / 4-1 b ., 25 \mathrm{c}$.

\section{COLLARDS}

\section{Postpaid}

CULTURE-Sow seed as for Cabbage in June, July and August for succession; transplant when one month old in rows a foot arart each way and hoe often.

GEORGIA, SOUTHERN, or CREOLE-This is a variety so extensively used in the large, loose, open head, or a mass of leaves on a tall stem. Freezing improves their quality. Pkt., $5 \mathrm{c}$; oz., $10 \mathrm{c} ; 1 / 4-1 \mathrm{~b} ., 25 \mathrm{c}$.

\section{CRESS OR PEPPER GRASS}

\section{Postpaid}

Cress-Mastuerzo-ojaertun-Kresse.

GARDEN CRESS Or PEPPER GRASS-Per pkt., $5 \mathrm{c} ;$ oz., $10 \mathrm{c} ; 1 / 4-1 \mathrm{~b} ., 20 \mathrm{c} ; 1-1 \mathrm{~b} ., 75 \mathrm{c}$.

Plant on rich soil, finely pulverized, in drills six or eight inches apart. To be used as a salad before the flowers appear.

\section{CELERY \\ One ounce will make about 2,500 plants. Postpaid.}

CULTURE-Sow the seed in a light, rich, dry horder as early as the ground can be worked, in drills eight $\neg r$ ten inches apart, and cover the seeds about a quarter of an inch deep rolling or treading them in if the ground be dry. When fairly out of the seed leaf they may be transplanted to another bed, or they may be thinned out in beds or trenches. The bed should be kept well weeded, and an occasional soaking with water in dry weather will do the plants good. Early in June is the proper time to set the plants out in beds or trenches. Press the soil firmly against the roots. In the garden the better way is to set the plants in shallow trenches-we say shallow, for it is obviously a bad plan to remove all the good soil (as must be done in a deep trench) and put the plants in that which is poor. "The plants may be set in a single row in a narrow trench, or the trench may be made into a bed wide enough to hold two, three or four rows, and in that case the plants are in a compact form, to be covered for the winter where they grow. 
CHINESE CELERY-One of the choicest sorts known; crisp, tender and delicious. For market and home use is unequalled; is a good keeper, and grown almost exclusively by celery growers in Utah. Oz., 50c; 1/t 1b., $\$ 1.90 ; 1$ lb., $\$ 7.00$.

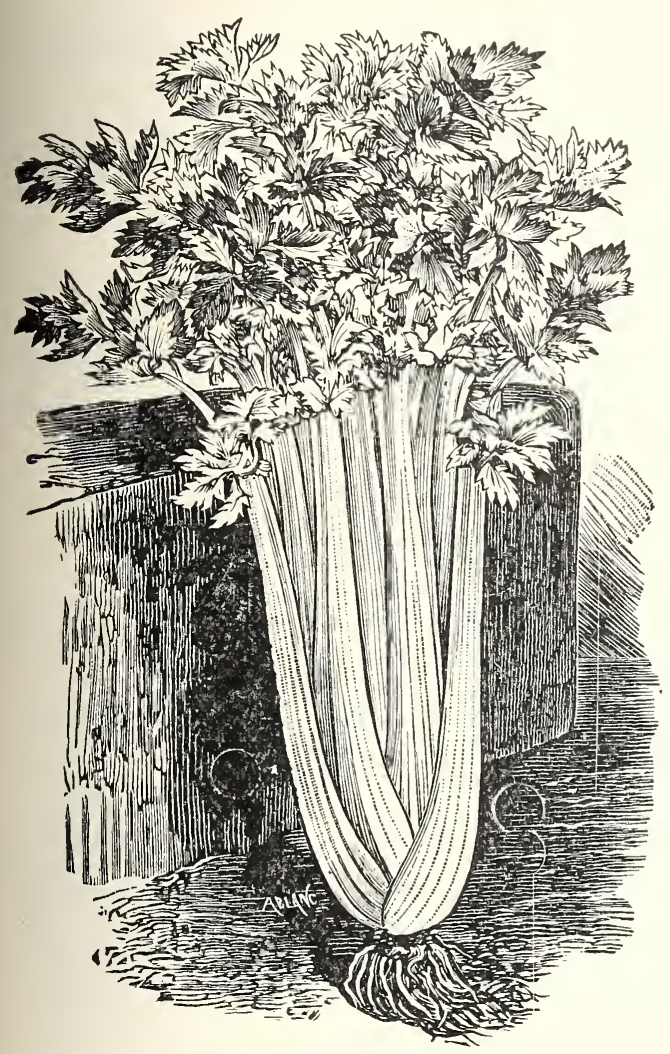

CHINESI: CELERY

Postpaid.

CULTURE-Egg Plant seed should be sown in hot-beds in March or April and transferred to pots or boxes when an inch or two high and planted out early in June in rows $21 / 2$ feet apart each way, cultivation same as for cabbage.

NEW YORK IMPROVED-The leading sort for home and market. Plant is a vigorous grower. Fruit large, fine and free from thorns and will produce until cut down by the frost. Skin is rich purple, flesh white and a fine flavor. We recommend this highly. Per pkt., 5ic; oz., $30 \mathrm{c} ; 1 / 4-1 \mathrm{~b} ., \$ 1.00$.

\section{ENDIVE}

Postpaid.

WHITE CURLED-A very beautiful sort in which the leaves are very light colored, even the outer ones being nearly white. Plant moderately dense with divided leaves which are a little coarser than those of the Green Curled. Per pkt., 5c; oz., 10c; $1 / 4-1 \mathrm{~b} ., 35 \mathrm{c} ; 1 \mathrm{~b} ., \$ 1.00$.

\section{KOHL-RABI}

\section{Postpaid.}

CULTUR:-Sow the seed in the spring in drills three-fourths of an inch deep and 2 feet apart and when the plants are a few inches high thin to 12 inches. Cultivate same as beets.

WHITE PLUME-This celery is valued because, naturally, thestalks and portions of the inner leaves and hearts are white; by simply tying up the stalks and drawing u'p the soil with the hoe, the work of blanching is complete. It is ornamental, tender, crisp, and of good flavor, and very early.

Pkt., 5c;oz., 20c; $1 / 41 \mathrm{~b}:, 75 \mathrm{c} ; 1 \mathrm{~b} . \$ 2.75$

GOLDEN SELF-BLANCHING-The plant is of beautiful appearance, of close habit and compact growth and straight, vigorous stalks. The ribs are perfectly solid, crisp, brittle and of delicate flavor, surpassed by no other variety, while it has the decided merit of being self-blanching to a very remarkable degree. Our stock of this variety is selected with special care in France. It is the strain for market gardeners, also family garden.

Pkt. 5c; Oz., 20c; 1/4-1b., 75c; lb., \$2.75

GIANT PASCAL-This is a greenleaved variety. It blanches very quickly after earthing up, when it is of a beautiful yellowish-white color, very solid and crisp, and of a nutty flavor, which cannot be equaled by any other sort. The stalks grow broad and thick, a single plant making a large bunch. Under high culture this variety will give the best satisfaction. Pkt., 5c; oz., $20 \mathrm{c} ; 1 / 41 \mathrm{~b} ., 75 \mathrm{c} ; 1 \mathrm{lb} ., \$ 2.75$.

\section{CELERIAC OR TURNIP ROOTED CELERY.}

Grown for the edible root and not for the greens. Start seed like celery and transplant to garden. Giant Smooth Prague. - Celeric forms a good thick root, as much as four inches in diameter, and nearly globular. Makes a most delicious flavored salad. Pkt., 5e; oz., 15e; 1/4-1b., 50e; 1b., \$1.25.

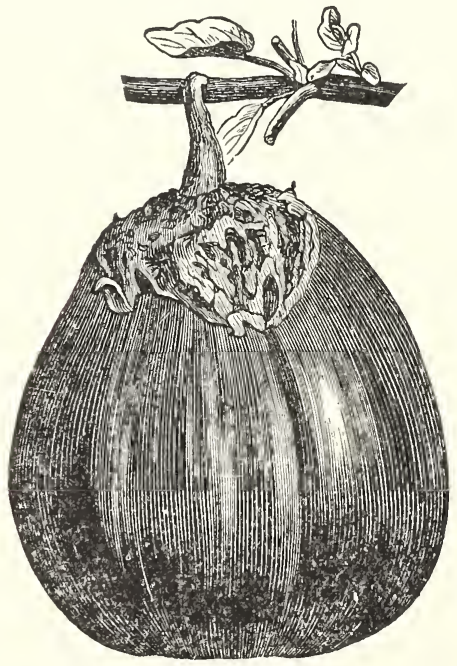

New York Improved. 


\section{KOHL-RABI}

\section{Postpaid}

BARLY WHITE VIENNA-The earliest and best for forcing; very tender; excellent for table use. Pkt. $5 \mathrm{c}$; oz., $15 \mathrm{c} ; 1 / 4-1 \mathrm{~b} ., 50 \mathrm{c}$.

\section{KALE OR BARECOLE}

CULTURE-More hardy than cabbage and makes excellent greens. Improved hy a touch of frost. Sow in May and June, cultivate same as cabbage.

\section{HORSE RADISH}

\section{Postpaid.}

Horseradish produces no seed, but is grown from pieces of the root.

CULTURE-Mark off rows two and one-half feet apart, in rich, moist, well-prepared ground and set the pieces of root eighteen inches apart in the rows, vertically, the small ends down. Cultivate until the tops cover the ground, when their shade will keep down the weeds. Small roots, $30 \mathrm{c}$ per doz., $\$ 1.00$ per 100 , postpaid.

\section{GARLIC}

\section{Postpaid.}

Garlic is the most pungent of all the onion family. It is much used in the South of Europe. The root or bulb is composed of many small bulbs called "cloves" which are planted in the spring six to eight inches apart, and in August the tops will die, when the bulbs are ready to gather. They do best in light, rich, soil. Bulbs, 1-lb., 40c. Write for prices on larger lots.

\section{LETTUCE}

\section{Postpaid}

CABBAGE OR HEADING VARIETIES.

One ounce will produce about 3,000 plants.

CULTURE-Sow in the house or in frames any time after March 10th; if put outdoors, as early in the spring as ground can be worked and at intervals of two weeks till June 1 st. Soil should be a rich, sandy loam with plenty of humus. Rows to be $11 / 2$ feet apart, plants two inches apart in row after thinning. Two ounces of seed will sow 150 feet of row, 4 to 5 pounds required per acre.

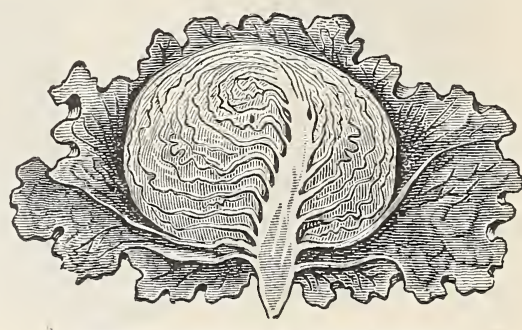

NEW YORIK OR WONDERFUL

NEW YORK OR WONDERFUL-This is now the most popular of main crop head lettuces. The heads are very large, wonderfully solid, crisp, tender, and free from bitterness. The heads frequently weigh three pounds. They are very solid and of an attractive light green color. It is a sure heading variety and stands a long time in the field. If you want fine head lettuce, either for market or home use try New York. Pkt., 10c: oz., 20c; 1/4-1b., 75c; 1-1b., $\$ 2.50$.

EARLY PRIZE HEAD-It forms a mammoth head and remains tender and crisp throughout the season; is prompt to head, but slow to seed; of superior flavor and very hard. The leaves are very large, crimped, bright green tinged with brownish red on edge. Pkt. $5 \mathrm{c} ;$ oz., $20 \mathrm{c} ; 1 / 4-1 \mathrm{~b} ., 50 \mathrm{c} ; 1 \mathrm{lb} ., \$ 1.25$.

HANSON-The heads are of very large size, delicately sweet, tender and crisp even to the outer leaves; heads weigh two and a half to three pounds and measure about one and a third feet in diameter. Color, green outside and white within: free from any bitter, unpleasant taste. Not recommended for forcing, but has few superiors for family use. Pkt., 5c; oz., $20 \mathrm{c} ; 1 / 4-1 b ., 50 \mathrm{c} ; 1$ lb., $\$ 1.25$.

\section{CURLED OR LOOSE LEA VED LETTUCES.}

SIMPSON'S EARLY CURLED-One of the best early sorts for market or family use. All the leaves tend to produce a large loose head. Leaves beautifully crimped, dark green, very tender and crisp. Recommended for general eultivation. Pkt., 5c; oz., 20c; $1 / 4-1$ lb., $50 \mathrm{c} ; 1$ lb., $\$ 1.25$.

\section{LEEK}

CULTURE-Sow seed in early spring in rows 1 foot apart and 1 inch deep. When 6 inches high, transplant 4 to 6 inches apart in rows 12 inches apart, setting plants in the ground up to their center leaves and as they grow draw the soil up around them.

IARGE AMERICAN FLAG-This leek, aside from being valuable for soups and salads, when blanched, makes an excellent dish when sliced and cooked like green peas. Per pkt., 5c; oz., 15c; 1/4-1b., 50c; 


\section{MUSTARD}

\section{Postpaid.}

Mustard is not only used as a condiment, but the green leaves are used as a salad or cut and boiled like a spinach

GIANT SOUTHERN CURLED-The large leaves, which often measure fourteen inches are ready for use in about six weeks after sowing. Plant will continue to yield until frosty weather. Leaves are eaten, boiled 11ke spinach. Per pkt., 5c; oz., 10c; 1/4-1b., $25 \mathrm{c} ; 1 \mathrm{~b} .90 \mathrm{c}$.

1b., $40 \mathrm{c}$.

\section{CANTALOUPE OR MUSKMELON}

\section{One ounce will plant about 60 hills. Three pounds per acre.} Pkt., Je; oz., 10c; 1/4-1b., 25e; 1-1b., 90c. .Postpaid.

CULTURE-Muskmelons delight in moderately rich, warm, mellow loam. The seed should be planted in the spring upon the arrival of settled warm weather. Plant seeds 1 inch deep in hills, 4 to 6 feet apart each way, and as soon as the plants begin to run, remove all but 4 of the most likely ones.

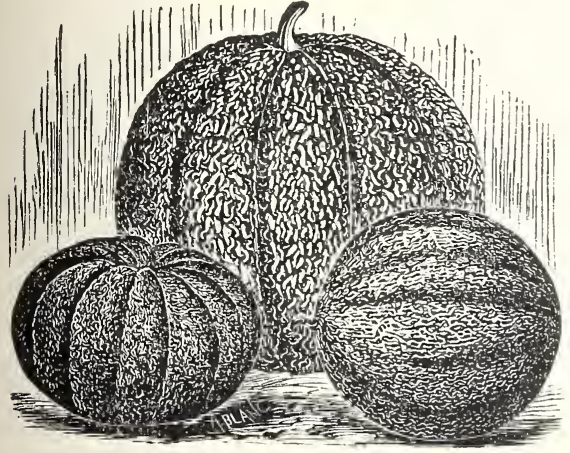

GROUP OF MELONS.

THE ROCKY FORD CANTALOUPEMost valuable introduction; has attained in an incredible short time a national reputation. It is the Netted Gem type, oval in shape, averaging from four and onehalf to five inches in length, of a delicious flavor, very fine and smooth-grained flesh of a light green color throughout when ripe, from the district in which it has been for the past several years so extensively grown, Rocky Ford, Colorado.

EXTRA EARLY CITRON-A decided acquisition among cantaloupes. Earlier than any other; large, showy and of fine flavor. A variety which for its early maturity will be found profitable by all market gardeners and desirable also in the private garden till others come into condition. EXTRA EARLY HACKENSACK-By
careful carried on for some years this strain has been so developed that it produces melons with all the good qualities of the well-known Hackensack melon, but at least ten days earlier

NETTED GEM-This has become one of the most popular of small or basket melons. The fruit is oval, slightly ribbed, densely covered with coarse netting. Flesh thick, green, very sweet and highly flavored. We offer an exceptionally fine stock of this sort.

MONTREAL MARKET-This fruit is nearly round, flattened at the ends and deeply and very regularly ribbed; skin green, deeply netted; flesh remarkably thick, light green, melting, and of a delicious flavor. They are very regular in shape and uniformly grown to a very large size. To all who desire to raise the handsomest melons possible for exhibition, or extra large, fine melons for market, we highly recommend these.

CASSABA-Long, oval-shaped; skin very thin and delicate; flesh extremely tender rich and sweet, and fiows copiously with a cool juice, which renders them very grateful.

BANA NA. (Yellow Flesh) - A very curious melon; attains a length of eighteen to twenty inches and a diameter of two to four inches. Looks and smells like a banana.

EMERALD GEM-Fruit small to medium sized; globular or slightly flattened at the ends; only slightly netted and ribbed; skin deep green while young, becoming tinged with yellow as the fruit matures; flesh deep salmon yellow, thick, ripening close to the rind and exceedingly high flavored.

OSAGE or MILER'S CREAM-A remarkably fine variety and very profitable sort for market gardeners. It is of medium size, oval in form, dark green in color; handsomely netted and slightly ribbed. The flesh is extremely and uniformly thick; of firm texture; rich salmon in color.

BURRELLS GEM-Same shape as the Rocky Ford Cantaloupe, a trifle larger; pink flesh. This new melon surpasses all others for its delicious flavor, and is a gen. eral favorite.

WINTER CASABA-Improved Hybrid-Has a deep green color outside, deeply ribbed. The flesh is creamy white, two to three inches in thickness. Size 8 to 12 lbs. Requires 110 to 120 days to make. Should not be eaten until it becomes soft or mellow after picking. Will stand shipping across the continent. Plet. $5 \mathrm{c} ; 0 \mathrm{z}$., $20 \mathrm{c} ; 1 / 4-1 \mathrm{~b} ., 75 \mathrm{c}$.

ROBINSON'S GOLD IINED CANTALOUPE-An improved strain of the Eden Gem type. The shape is ideal, no ribs, heavily netted, thick-meated. The color is green with gold margin. Highly recommended. Comes to us in sealed packages of 1 and $51 \mathrm{bs}$. Per pkt., 5c; oz., $15 \mathrm{c} ; 1 / 4-1 \mathrm{~b} ., 50 \mathrm{c} ; 1-1 \mathrm{~b} ., \$ 1.50$.

POLLOCK-10-25-This is a standard shipping Melon, also desirable for home and the Market Garden. The flesh is a rich salmon two thirds of the debth changing to green near the rind. Very small seed cavity. Similiar to the Rocky Ford, but larger, and not quite as early. HARTS OF GOLD, OR IMPROVED HOODOO-An oblong type, little larger than the Rocky Ford. Orange color. A very choice type for Market growing. 


\section{WATERMELON}

Per plkt., äe; oz., 10e; 1/4-1b., 2.̌c; 1-1b., S0e. Postpaid.

CULTURE-The soil for Watermelons must be light, rich and sandy, for if grown on a heavy soil the quality will be poor and they will not be so early. When there is no more danger of frost, drop $\delta$ to 10 seeds in a hill 8 to 10 feet apart each way, cover about three-fourths inches deep. As soon as plants commence to run, thin out to 3 best plants in a hill and cultivate until the vines cover the whole ground. If slow to fruit pinch off the ends of the growing shoots. Ashes or air-slacked lime sifted on the young plants while dew is on is good to keep the insects out. One ounce will plant about 130 hills, and it takes 4 to 5 pounds to one acre. Ready for use in 60 to 90 days.

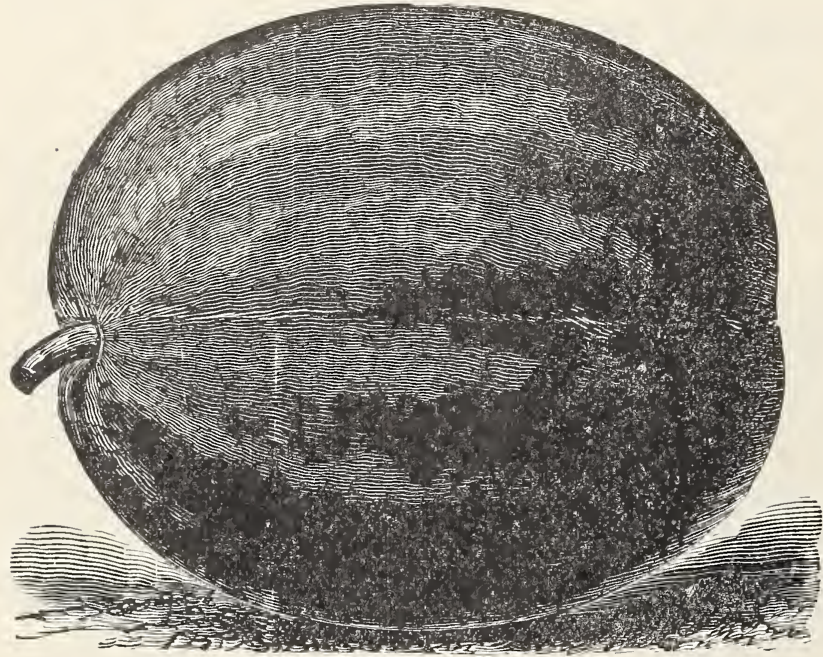

PHINNEY'S EARLY

PHINNEY'S EARTYFlesh deep red, of very superior quality; early and productive; a very valuable market variety.

COLE'S FARLY - Is very early and will mature in every state. Melons are of medium size, nearly round in shape; rind $\mathrm{gre}$ e $\mathrm{n}$ striped with light.

MOUNTAIN SWEETFruit of large size and oval shape; flesh scarlet and quite solid; very sweet and delicious; best for general use.

ROCKY FORD-This melon, as indicated by its name, was originated at Rocky Ford, Colorado. It is well known to be the best shipping melon grown, while its flavor is far superior to any other melon.

SWEET HEART-This new melon is early: large, handsome, heavy and productive. Th $\mathrm{e}$ shape is oval and color mottled light to ver'y

light green. Flesh bright red; solid but tender and very sweet.

CUBAN QUEEN-Fruit large and solid; rind very thin and strong; ripens to the very center; skin striped with dark and light green; flesh bright red, crisp and very sugary. It is an excellent keeper and bears transit well.

SEMINOLE-A large and very productive melon; color usually gray, sometimes a light green; flesh carmine, of good quality and flavor; green and gray melons on same vine; good shipper.

GYPSY, or RATTLESNAKE-The largest of all the varieties of watermellons; long, smooth, distinctly striped with light mottled and wavy, dark green, regular stripes; flesh bright scarlet and very sugary; thin skinned, but bears carriage well, which together with its large size, will make it an exceedingly popular late market variety.

TOM WATSON-This is undoubtedly the largest and best watermelon grown, being a long striped variety of splendid flavor and texture. Specimens of this watermelon were exhibited at the Utah State Fair last fall, weighing 80 1bs. GIVE IT A TRIAL.

KLECKLEY'S SWEE'T-This melon is of a splendid sort for home use or near markets; vine vigorous and productive; fruit medium size; oval; color, dark mottled green in two shades, forming indistinct stripes; flesh very bright, rich red and exceedingly sweet. This variety is so crisp and tender that it will not stand shipping, the fruit bursting open if subjected to even a slight jar or when the rind is penetrated with a knife.

FLORIDA FAVORI'TE-A very large, long melon, mottled, dark green with stripes of lighter shade; rind thin but firm; flesh very bright, deep red; very sweet, tender and excellent. A very popular variety in the south.

CITRON-Grows uniformly round and smooth, striped and marbled with light green; flesh white and solid; seeds red. This variety is not used for eating in the raw state, but for preserves, pickles, etc. 
KING AND QUEEN WINTER WVACRMLLON-Average weight 20-1bs.; the most handsome and valuable melons in the world. It is very hardy, does well in any soil which grows melons, never sets an imperfect specimen on its vine, ripens every melon in less than 120 days; has not yet crossed with any other melon; has all within itself to produce; its good qualities reflect its intelligence; it knows no higher source, and refuses to associate with anything below it. It is mother and father of all melons. This is why a lady at the Salt Lake fair gave it the name of King and Queen. It is a prize taker anywhere. These melons have been shipped into this market as late as December, and have sold at 5 cents per pound to the dining car service of the Rio Grande Western. Ripens on the vine third week in August and does not change its conditions for ninety days if not bruised. Shell is as hard as an egg and the melon ripens to within one-eighth of an inch of the shell. Pkt. 5c; oz., 15c; 1/4-1b., 35c; $1-1$ b., $\$ 1.25$.

\section{ONIONS}

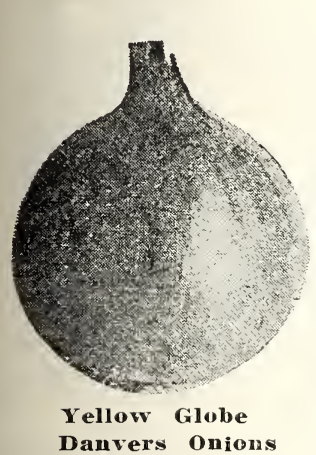

\section{Postpaid.}

CULTURE-Soil for Onions should be rich in humus and plant food. Fresh stable manure and barnyard litters are entirely out of place on the Onion field. They are usually loaded with weed seeds and will interfere very much with tillage. Compost heaps will destroy the weed seeds and put the manures in such condition that they will readily mix with the soil. Manure from sheep sheds or pig pens applied with a spreader before the ground is plowed in the Fall makes excellent fertilizer for Onions because it is usually comparatively free from litter and foul seeds.

VELLOW GLORE DANVERS-A very excellent variety of globular shape, reliability for bottoming and large yield are both combined in this popular sort. It is grown extensively for market, and very popular. It is a handsome onion, quite thick, though of good size, with thin, yellow skin; flesh white, fine-grained and mild and good keeper. Per pkt., 5c; oz., $25 \mathrm{c} ; 1 / 4$ lb., $\$ 1.00 ; 1$ lb., $\$ 3.75$.

DANVERS YELLOW FLAT-Similar to the Yellow Globe Danvers except in shape. Ripens very quick, is a sure cropper and yields well. Of special value in lncalities where the seasons are short. Will stand drought well and is used to a large extent for growing onion sets. Per pkt., 5c; oz., $25 \mathrm{c} ; 1 / 4 \mathrm{lb}$., $90 \mathrm{c} ; 1$ lb., $\$ 3.00$.

BROWN AUSTRALIAN-Is of medium size; wonderfully hard and solid: the bulbs are most attractive for market, both as to form and appearance. They ripen evenly and extremely early; never showing any thick necks or scullions. The color of the skin is of a pale reddish brown, distinct from that of any other variety. Per pkt., $5 \mathrm{c} ; 0 \mathrm{z} ., 25 \mathrm{c} ; 1 / 4-1 \mathrm{~b} ., 90 \mathrm{c} ; 1-1 \mathrm{~b}$. , $\$ 3.00$.

PRIZE-TAKER-This new variety is without exception the largest and most handsome variety of onions ever grown. It is the large, beautiful onion that is seen every fall on sale at the fruit stores and stands in the large cities. The outside skin is rich yellow, straw color, while the flesh is white, sweet, mild and tender. Per pkt., 5c; oz., 25c; 1/4 lb., \$1.0t; 1-1b.,\$3.00.

EARLY WHITE QUEEN-Succeds well everywhere. The bulbs are small, flat beautifully white and of excellent flavor; but the principal recommendation is the niarvelous rapidity of its growth. An excellent sort for pickling onions. Per pkt., 5c; oz., $25 \mathrm{c} ; 1 / 4-1 \mathrm{~b} ., 90 \mathrm{c} ; 1-1 \mathrm{~b} ., \$ 3.00$.

WHITE PORTUGAL, or SILVER SKIN-A mild, pleasant flavored variety; the thin skin a clear, silvery white of very handsome appearance; the bulbs grow to a good size, ripening early and quite evenly. Per pkt., 5c; oz., 25c; 1/4-lb., 90; 1-1b., \$3.00.

MAMMOTH SILVER KING-This new onion grows to a most remarkable size. The skin is a beautiful silvery white; the flesh is snowy white and of a particularly mild and pleasant flavor. Per pkt. $5 \mathrm{c} ;$ oz., $25 \mathrm{c} ; 1 / 4-1 \mathrm{~b} ., 90 ; 1-1 \mathrm{~b} ., \$ 3.00$.

LARGE RED WETHERSFIELD-This is the standard red variety and a favorite onion in the east, where immense crops are grown for shipment. Bulb large, somewhat flattened, oval-shaped; skin deep purple red; flesh purplish white, moderately fine grained and rather strong flavored. Very productive; the best keeper and one of the most popular for general cultivation. Per plt., $5 \mathrm{c} ;$ oz., $20 \mathrm{c} ; 1 / 4-1 \mathrm{~b} ., 90 \mathrm{c} ; 1-1 \mathrm{~b} ., \$ 2.50$. 
SOUTHPORT RED GLOBE-This most excellent medium early or main crop red varlety produces bulbs of medium to large size, ideally globe shaped, with very smooth, glossy surface, very small neck and remarkably beautiful deep purplish red color. The flesh is white, tinged with light purple, mild, very fine grained and tender. The variety is extensively grown for home use as well as the market. It is one of the bost keepers and is well adapted for shipping. Pkt., 5c; 0z., 15c; 1/4-1b., 50c; 1-1b., \$1.90.

SOUTHPORT WHITE GLOBE-Ylield abundantly, producing handsome and uniformly globe-shaped bulbs. The flesh is firm, fine grained and of fine flavor. Pkt., 5c; oz., $15 \mathrm{c} ; 1 / 4$ lb., $50 \mathrm{c} ; 1-1 \mathrm{~b} ., \$ 1.50$.

\section{LARGE SPANISH ONIONS}

Pkt., 5c; oz., 25c; 1/4-1b., 90c; lb., \$3.00.

Postpaid.

SWEET SPANISH GENUINE VELENCIA TYPE-This Large Mild, extremely productive Globe shaped onion has become a great favorite in Utah and Salt Lake County during the past two or three years on account of the excellent market and large yield per acre. One Provo farmer measured one square rod in his patch, harvested the onions and they weighed $400 \mathrm{lbs}$. One half acre netted him $\$ 500.00$ at $\$ 1.50$ per 100 lbs. Pkt., 10c; oz., 70c; $1 / 4-1 b ., \$ 2.25 ; 1$ lb., $\$ 8.00$.

GIANT GIBRALTAR-Large brownish yellow, somewhat flattened on under side; often weighing four pounds. Is a good keeper and is known to be adapted to climatic conditions of Utah. They have been grown here for the past five years and have produced as high as 1,900 bushels per acre, and as sweet and tender as an apple.

MAMMO'TH SILVER KING-The Earliest Giant White onion-The skin is a beautiful, silvery white. The flesh is sweet. Mammoth Silver King onions is from 5 to $7 \frac{1 / 2}{2}$ inches.

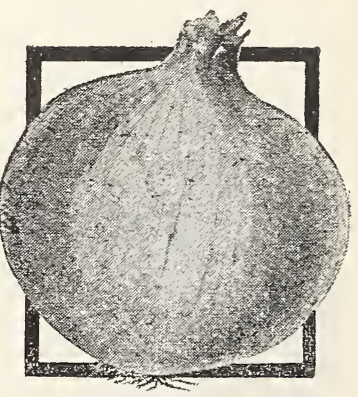

Giant Gibraltar Onions

AILSA CRAIG-Large, light yellow, globe. Average weight of 600 onions from one row (not selected) $21 / 2$ lbs. Extra selected 3 lbs., 9 oz. Probably the largest and heaviest cropping onion.

DENIA OR MAMMOTH PRIZETAKER-The Handsomest, Largest Yellow Globe onion-A good keeper, of finest flavor, handsome shape and enormous size, many single onions having been raised to weigh five pounds or over from seed the first year. The Prizetaker grows always to a perfect globe shape with a bright strawcolored skin.

PICKLING-EXTRA EARLY BARLETTA-It is fully two or three weeks earlier than the Early White Queen, which herelofore has been the earliest variety in cuitivation. They are of a pure, paper-white color, very mild and delicate in flavor; from one inch to one and one-half inches in diameter and three-fourths of an inch in thickness. Per pkt., 5c; 0z., 25c; 1/4-1b., 90c; 1-1b., $\$ 3.00$.

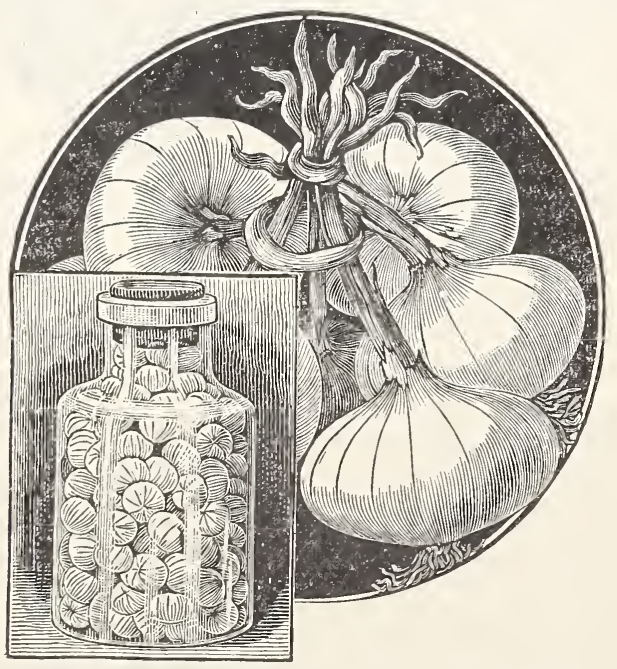

WHITE BARLE'T'TA.
ONIONS SETS. NOT POSTPAID. See Page 38 for Postage Rates.

Prices given are subject to market fiuctuations. When you want large quantities ask for market prices. Thirty-two pounds constitute a bushel.

One quart will set 75 to 100 feet of row, depending upon the size of the sets.

Per quart, 15c; bushel, \$4.00.

RED BOTTOM-Produced by sowing thickly the seed of the Large Fed Wethersfield variety and thinning out. They mature under this method when about half an inch through. They are then used precisely as top onions are, set them out in the spring instead cf sowing the seed.

YELLOW BOTHOM - Identical with the preceding, except in color. They are used in the same manner and are produced from the black seed of the Yellow Danvers variety.

WHI'TE BOT'POM-The seed of the White Silver Skin or White Portugal varieties is used to produce the white sets. They do not keep as well as the red or yellow, but produce beautiful white onions early in the season.

In bushel lots add $50 \mathrm{c}$ per bushel for postage. 


\section{PARSLEY}

\section{One ounce will sovv 150 feet of drill. Postpaid.}

CULTURE-Soak the seeds a few hours in luke-warm water, and sow early in the spring until the middle of July, in drills one foot apart. Thin out the plants to four inches. To preserve in winter transplant to a light cellar or cold frame.

NEW EMERALD-The plants are of dwarf, compact growth, whlle the leaves are of a handsome bright-green coloring, very finely crimped and curled, of most ornamental appearance. One of the finest for garnishing or flavoring. Commands the highest price in Denver markets. Pkt., 5c; oz., 10c; 1/4-1b., 30c.

CHAMPION MOSS, or TRIPLE CURLED-The leaves are finely cut and curled and of a dark-green color. Extra fine for garnishing and culinary purposes. Pkt., 5c; oz., $10 \mathrm{c} ; 1 / 4-1 \mathrm{~b} ., 20 \mathrm{c}$.

\section{PEAS-EARLY}

\section{Not Postpaid. See page 38 for Postage Rates.}

$1 / 4$ lb., 10c; 1/2 lb., 20c; 1b., 30c; 5 lbs., \$1.25; 10 lbs., \$2.25. Postage Extra.

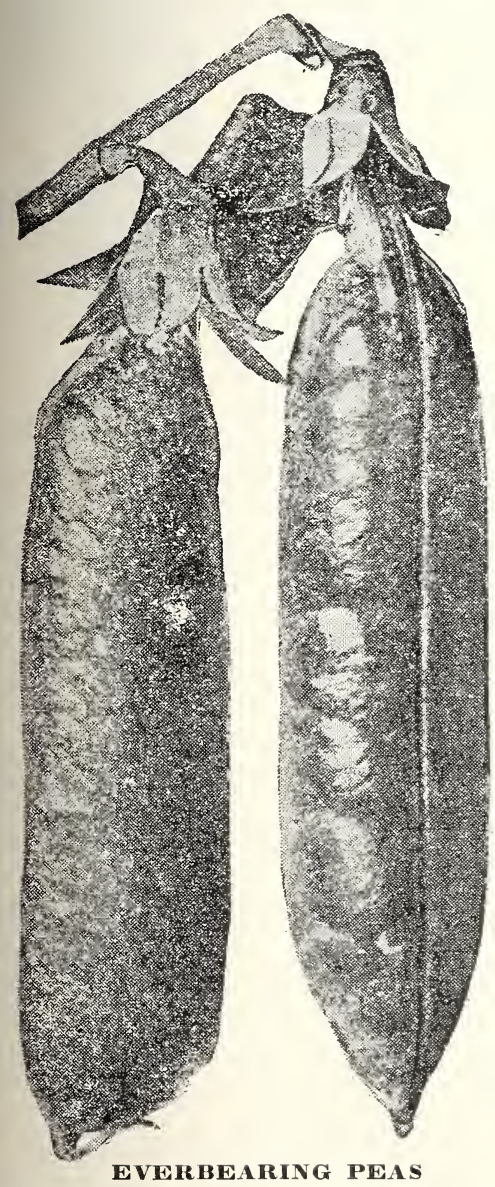

FIRST AND BEST-One of the earllegt smooth peas known; very desirable for market gardeners. It matures for table forty-five days from germination.

ALASKA-A variety of remarkable ear. liness and hardiness. It is a good yielder and produces pods of good size and dark, round smooth peas of splendid flavor, green in color, pods are well filled: height one foot; the color of the dried pea is green; it ripens very evenly, so that one picking will nearly clean off the crop

AMERICAN WONDER-This pea is a hybrid of fixed habit, between the Cham. pion of England and the Iittle Gem; it possesses the merits of both, with some additional claims to notice. The vine grows eight to ten inches high. and is very prolific in pods of striking form and size. In maturity it is among the first earliest. ripening in about fifty days from germina. tion. It is among the first early of the green wrinkled sorts. Its hablt is so dwarf that it can be very successfully grown under glass.

NOT'T'S EXCELSIOR-Robust and vigorous in growth, inclined to throw out lat. terals from the base of the stock, produc. ing in profusion long, handsome pods closely packed with large peas of fine flavor. An improvement on American Wonder, being more vigorous and prollite with larger pods, more peas than elthor the Wonder or Premium Gem. A declded acquisition and sure to be very popular when generally known; height, 12 inches.

LTTTLE GEM-A very desirable early dwarf, green wrinkled varlety; very popular and more prolific than the Little Gem.

GRADUS-The most attractive novelty of recent years; large, handsome pods resembling Telephone in size and shape, well filled with large peas, ripening with the earliest; is certain to be eagerly sought. Ripening very quickly, the pods must be picked as soon as fit for the table. Habit vigorous, vory quick to germinate and push to maturity; foliage large, pale green in color; pods long, straight, slightly rounded at the point. Seed large, wrinkled, cream color. 
PEAS-MEDIUM AND LATE.

EVERBEARING-The vines attain a height of from eighteen inches to two feet; foliage large; the pods will average four inches in length, each pod producing six to eight wrinkled peas. The peas are very large, being half an inch and over in diameter, and in quality unsurpassed. For a continuance in bearing this variety is unexcelled.

STRATEGEM-Seeds green; wrinkled; middle crop; one of the best peas ever sent out; grows a vigorous and showy vine, of branching habit; heavily laden with immense pods containing ten to twelve peas of large size; a marvelous cropper and incomparable eating pea; height, one and one-half feet.

TELEPHONE-This new variety is one of the finest Dwarf wrinkled, Dwarf vine-variety yet introduced. It is immensely productive, of the finest quality and of excellent sugary flavor; vine very strong, averaging eighteen to twenty pods per stalk; the pods are of large size and closely packed with six or seven large, delicious peas, height, about two feet.

CHAMPION OF ENGLAND-A variety possessing merit of high order. Superior to the common Marrowfat, which it resembles in strength of vine and general habit, wrinkled and very sugary; requires sticking; ripens for table use seventy days after germination.

DWARF GRAY SUGAR, Edible Pods-This is the most desirable of all edible pod peas. It is a new variety, growing only 1 foot high, and is remarkable for its prolific character. The seeds are large, shriveled and indented, of a dark brown color. The pods are flat and crooked; and contain five or six peas. A very desirable acquisition.

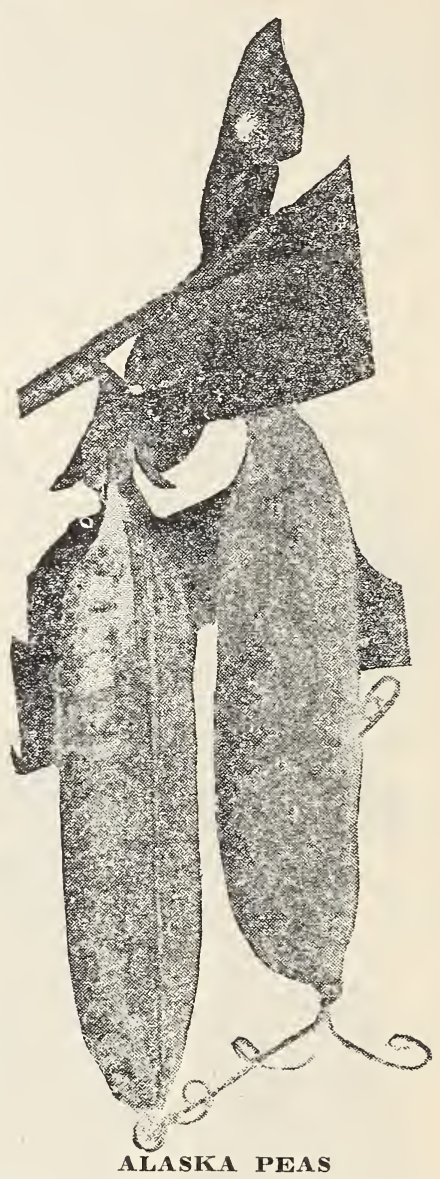

\section{SEED POTATOES}

\section{Write for Prices.}

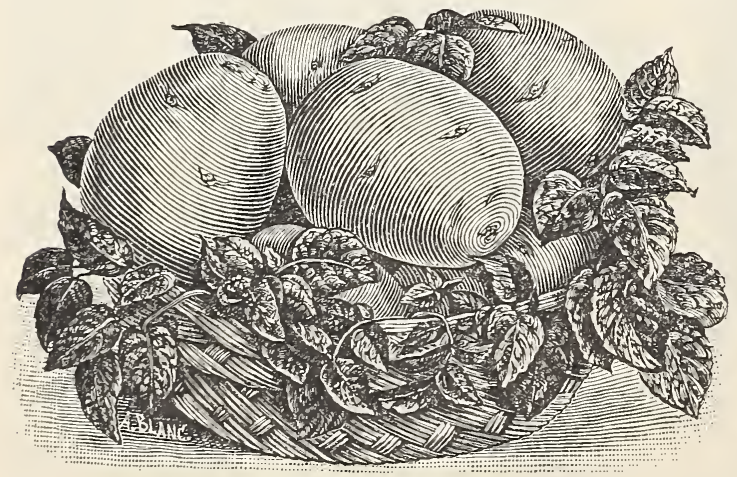

EARLY OHIO
IRISH COBBLER-Irish Cobbler has been for some years the most famous early potato in the East. In the potato sections of Maine it has been more largely grown than all other earlies and has been shipped from there in large quantities to supply truckers of New Jersey and Virginia and other Atlantic coast states. From these its popularity has extended throughout the whole of the United States. 
IMPROVED EARLY OHIO-Early Ohio is without doubt the most popular early potato in the country. We have more calls for it always than fol any other early. Every one knows what it is, and knows that it can be relied on for an early market variety in almost every locality. A large percentage of the so-called Ohios throughout the country, however, are badly mixed and are run out. The worst of it is many farmers do not seem to know that their seed is mixed. It is even very common to find potatoes entered for exhibition at the fairs in the fall as Early Ohios that are all mixed up with Early Rose or some other variety with smooth skin and pointed ends. A typical Early Ohio should have blunt rounded ends, with the cluster of eyes at the seed end right out flush with the surface.

\section{PARSNIP}

\section{Postpaid.}

CULTURE-They do best in deep rich soil, but will make good roots on any soil which is deep and mellow and moderately rich. As the seed is slow to germinate, it should be sown as early as possible; cover one-half inch deep, and press the soil firmly over the seed; give frequent cultivation, and thin the plants 6 to 8 to the foot. As they are improved by frost, a part of the crop should be left in the ground for spring use. One ounce will sow 150 feet of drill, 5 pounds to an acre.

HOLLOW CROWN IMPROVED-The best for table use. Roots comparatively short, white and smooth, fine grained and excellent. A heavy cropper. Pkt., 5c; oz., 10c; 1/4-1b., $30 \mathrm{c} ; 1-1 \mathrm{~b} ., 90 \mathrm{c}$.

\section{PUMPKIN}

\section{I'ostpaid.}

The value and utility of this crop is not as generally appreciated as it should be. There is no crop that responds as well to poor soil or to new ground. Plant in hills 6 feet apart. One oz. to 30 hills, 3 to 4 pounds to the acre.

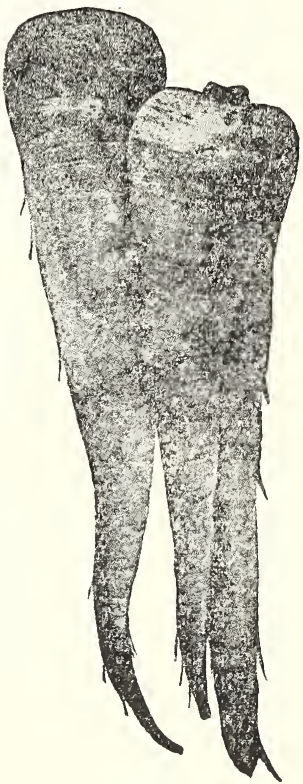

PARSNIP

CASHAW. or CROOKNECK-A French variety liked by many. Has yellow flesh, solid and sweet. Pkt., 5c; oz., 10c; 1/4-1b., 25c; 1-lb., $90 \mathrm{c}$.

KING OF MAMMOTH-The flesh and skin of a bright golden yellow color. Flesh fine grained, and of excellent quality. Notwithstanding its enormous size, it is one of the very best pie pumpkins ever grown and a splendid keeper. This enormous variet has been known to weigh over 200 pounds. Pkt., 5c; oz., 10c; 1/4-1b., 30c: 1-1b., $\$ 1.00$.

LARGE CONNECTICUT YELLOW FIELD-(Yankee Cow Pumpkin.) The standard field pumplkin. No farmer should fail to plant some every year with corn; a sure cropper, a good keeper, and very prolific-the best for stock, also good for pies. Pkt., 5c; oz., 10c; 1/4-1b., 20c; 1-Ib., 60c.

\section{PEPPERS}

\section{Postpaid.}

CULTURE-Sow in hotbeds in March, and when the soil has become warm, set in rows two feet apart and eighteen inches in the rows, hoe frequently and keep down all weeds. The plants may also be forwarded in pots. 
CHINESE GIANT-A very large pepper, of the Bull Mose type, often growing to five inches in diameter. This is the variety grown so extensively in frostless sections for the winter trade, when the grower gets as much as $20 \mathrm{c}$ per $1 \mathrm{~b}$, for the green pepper. One grower claims that his returns from five acres was \$4,500.00 Pkt., 5c; oz., $40 \mathrm{c} ; 1 / 4-1 \mathrm{~b} ., \$ 1.50$.

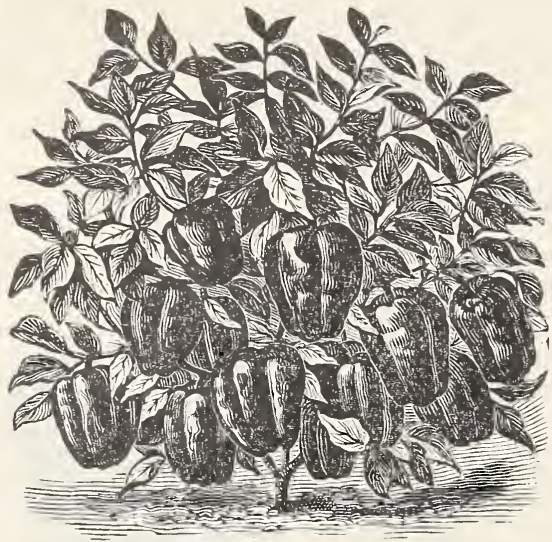

RUBY KING.

GOLDEN DAWN-Plants quite dwarf but very prolific. Fruit medium to large in slze of inverted bell shape, rich, golden yellow color, with very thick, sweet, mild-bavored flesh. Pkt., 5c; oz., 25c; 1/4-1b., 75c.

RUBY KING-An improved American varie. ty reaching the largest size, often four to six inches in length, yet retaining the same symmetrical shape of the smaller sorts. It is very bright colored, and the flesh is beau. tiful, sweet and mild-flavored. One of the best for stuffed pickles. Pkt. 5c; oz., 25c; $1 / 4-1 b ., 75 c$.

LARGE BELL, or BULL NOSE-An old standard variety. It is early, bright red in color at maturity, entirely mild, of large size and has thick flesh. Pkt. 5c, 0z. $25 \mathrm{c}, 1 / 4-1 \mathrm{~b} .75 \mathrm{c}$.

SWEET MOUNTAIN-Somewhat larger and milder than the Bull Nose. Its color is green turning red; very productive. Pkt., 5c; oz. $25 \mathrm{c} ; 1 / 4-1 \mathrm{~b}$., $75 \mathrm{c}$.

RED CHILI-A late variety, used in the manufacture of pepper sauce. The bright rich pods are about two inches long, one. third to one-half inch in diameter at base tapering. Pkt., 5c; oz., 25c; 1/4-1b., $75 \mathrm{c}$.

LONG RED CAYENNE-A rather late sort, having a slim pointed pod about four inches long and when ripe, of a bright red color. Extremely strong and pungent flesh. Pkt., 5c; oz., 25c; 1/4-lb., 75c.

\section{SALISFY OR OYSTER PLANT}

\section{Postpaid}

CULTURE-Sow the seed in the spring in drills one foot apart and one inch deep, thinning out plants to four inches. It succeeds best in light, well-enriched soil. One ounce of seed for 50 feet of drill.

MAMMOTH SANDWICH ISLAND-This new salsify recently introduced from the Sandwich Islands, grows fully double the size of the common variety, and is superior in quality. It is pure white in color, and is invaluable to market gardeners. Per pkt., $5 \mathrm{c}$; oz., $15 \mathrm{c}$; 1/4-1b., $45 \mathrm{c}$; 1b., $\$ 1.00$.

\section{OKRA}

\section{Postpaid}

\section{One ounce will plant 100 hills.}

CULTURE-Sow late in the spring, after the ground has become warm, in drills 3 feet apart, and, when plants are 3 inches high, thin out from 10 to 12 inches. They should be well manured. The young green seed pods of this plant are used in soups or stewed, and served like asparagus. The young pods can also be dried for winter use.

DWARF-Prolific, early, long podded and productive. Pkt., 5c; oz., 10c; 1/4-1b., 20c; lb., $75 \mathrm{c}$.

TAIL-Hight, 5 feet. Plant in rows of 3 feet, and let two plants stand to the foot. Pkt., 5c; oz., 10c; 1/4-1b., 20c; 1-1b., $75 \mathrm{c}$.

\section{RADISH}

One ounce will sow 100 feet of drill.

Plkt., 5e; oz., 10e; 1/4-1b., 25e; 1-1b., 75e. Postpaid.

CULTUPE-Do best in sandy loam of good fertility. The seed should be sown just as early in the spring as possible in rows 12 to 18 inches apart. Radishes must be given sufficient room to enable them to develop to full size without any check. It is, therefore, of great importance that they be thinned as often as necessary. The small round varieties should be from 1 to $1 \frac{1}{2}$ inches apart and the long ones 2 to 3 inches apart.

EARLY LONG SCARLET SHORT TOP-Grows six to seven inches long, half out of the ground; is very brittle and crisp, and of quick growth; color, bright scarlet; small top; tapers regularly to the root and is uniformly straight and smooth.

WHITE STRASBURG-The most valuable summer radish in cultivation; flesh pure snow-white, tender and of a pleasant, pungent taste, without being strong. 
WHITE-TIPPED SCARLET-A handsome very bright scarlet on top and shading to white on bottom; crisp and fine and very popular with Denver market gardeners; used more generally than any other kind.

EARLY SCARLET TURNIP-A small, round, turnip-shaped, with small top, and of very quick growth.

FRENCH BREAKFAST-A medium-sized radish, oliveshaped, small top, of quick growth, very crisp and tender, of a beautiful scarlet color.

NEW “ICICLE' - Entirely distinct, long, slender, pure white; very early; much the earliest and finest long white. It is ready for use earlier than the Isong Scarlet. Short Top, with less foliage, rendering it most desirable for forcing. Roots pure snowy white, four inches in length and half an inch in diameter; they retain their crispness and fresh, mild flavor until fully six inches long and an inch in diameter.

WINTER CHINA ROSE-Roots cylindrical, or largest at the bottom, tapering abruptly to a small top; skin very smooth, and of a bright rose color; flesh as solid as an apple; very good keeper.

WINTER BLACK ROUND SPANISH-One of the latest, as well as the hardiest of radishes, and is considered an excellent sort for winter use; roots turnip-shaped; very large size and firm texture.

SPARKLER RADISH-A favorite for the Market Gardener. Color Scarlet and White. Extremely quick to mature, being ready for the table in twenty days from planting. Skin very smooth. Attains a good size without getting pithy.

MIXED RADISHES-All kinds mixed together. Very desirable for planting, being early, medium and late varieties gives you fresh radishes continuously during the entire season.

\section{RHUBARB OR PIE PLANT}

\section{Postpaid}

CULTURE-Sow the seed in cold frame in the spring and as soon as the plants are large enough to transplant in rows 1 foot apart each way and cultivate. The follow. ing spring, plant out in rows 5 feet apart each way and each spring work into the soil a liberal supply of decomposed stable manure. Rhubarb roots are set out and cultivated as the above and this method gives edible rhubarb in a very short time.

LINAEUS-Early, large and tender. Pkt., 5c; oz., 15c; 1/4-1b., 45c; $1 \mathrm{~b} ., \$ 1.25$

VICTORIA-Very large. Later than Linaeus. Pkt., 5c; oz., 15c; 1/4-1b., $45 \mathrm{c} ; 1 \mathrm{~b} ., \$ 1.25$.

\section{SWISS CHARD}

VALUABLE FOR POULTRY The new Swiss Chard, or Spinach Beet. The plant grows from two to two and
one-half feet in height. The stalks are thick, broad and delicious when cooked and served in the same manner as asparagus. The Lucullus has large, pointed, crumpled leaves, which when cooked and served in the same manner as spinach are tender and fine flavored. Pkt., 5c; oz., $10 \mathrm{c} ; 1 / 4-1 \mathrm{~b} ., 25 \mathrm{c}$.

\section{SQUASH}

Pkt., 5e; oz., 10c; 1/4-1b., 35e; 1b., 90c. Postpaid.

CULTURE-Plant when danger of frosh is past and the ground has become warm. For bush varieties the hills may be five feet apart but allow six to eight feet for trailing varieties. Plant 6 or $S$ seeds to the hill and thin to three plants when they begin to vine.

WHITE BUSH SCALLOP-Earlier than any other summer variety. The skin is white and tender when ready for use, dwarf in habit and very productive.

MAMMOTH SUMMER CROOKNECK-It is the best summer squash, and for these reasons: It is twice as large as the ordinary summer Crookneck, far more warty and several days earlier. This combination of earliness, large size and wartiness, which adds so much to its attractiveness, makes it altogether the most desirable squash for the market or private garden.

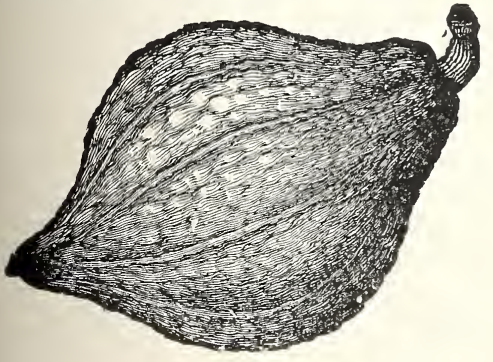

HA B BA RD.

HUIBBARD-The best table squash yet known, god specimens being about equal to the sweet potato. It has a hard shell, and with some care will keep three months later than the Marrows; flesh fine grained, dry and of excellent flavor.

CHICAGO WARTED HUBBARD-Improved and selected strain of the Hubbard Squash. Very popular in the vicinity of Chicago. The flesh is light orange; outer skin very dark green in color; very fine grained, solid and very sweet. For table use it is considered best of all.

SIBLEY'S-One of the best shippers, owing to the hardness of the shell. Flesh is solid and thick, a bright orange color and of choice quality. Flavor rich and sweet, and it ripens very early.

MAMMOTH CHILI-Although not new, we desire to call the especial attention of all who want "mammoth squashes," to this variety. Size enormous, often weighing 300 pounds; very profitable for stock feeding, especially when root crops are not grown extensively; remarkably productive.

GOLDEN HUBBARD-This is a very distinct sort of the shape and general character of the Hubbard, but a little smaller; earlier to mature and of rich orange red color, instead of the dark olive green of the old Hubbard, while the flesh is a little deeper colored and fully as good quality. 
DELICIOUS-All agree that Delicious is the finest flavored of all squashes. Grows to weigh 5 to 10 pounds, and is in its prime from early fall to mid-winter. Color a green shade with some blue specimens. In thickness of flesh it surpasses nearly every other variety. Cooks very dry and mealy, equal in quality to any sweet potato. By all means try Gregory's Delicious. Pkt., 5c; 0z., 10c; 1/4-1b., 30c; 1b., $\$ 1.00$. Postpaid.

HANANA SQUASH-This is not a new variety, but is considered one of the best winter varieties for home use, also excellent for feeding stock. Color and shape similar to banana, from whence it derives its name. Pkt., $5 \mathrm{c} ;$ oz., $10 \mathrm{c} ; 1 / 4-1 \mathrm{~b} ., 30 \mathrm{c} ; 1 \mathrm{~b} ., \$ 1.00$. Postpaid.

UTAH MAMMOTH FIELD-One of the largest Squashes grown. Single specimens weighing 17.5 pounds. An immense yielder and very profitable for feed. Matures early and should be extensively planted. Pkt. 5c; 1/4-1b., 15c; 1-1b., 50c.

\section{SPINACH}

One ounce will sow 100 feet of drill. Ten to twelve pounds for ona acre. Pkt., Jc; oz., 10c; 1/4-1b., 20c; 1-1bo, 50c. Postpaid.

CULTURE-For early spring use, sow seed in August in very fertile soil rich in humus. Upon approach of cold weather, cover the plants with 3 inches of straw. In the spring, when dry, remove the litter and the plants will be ready for use in a short time. Sow the seed 1 inch deep in rows a foot apart. For a succession, sow again early in the spring and every two weeks thereafter. Keep surface soil cultivated lightly.

LONG STANDING-An improved strain of excellent merit, having all the good qualities of the ordinary sorts; what renders it especially desirable is the fact that it is much later in going to seed than any other variety. This valuable quality will be appreciated.

BLOOMSDALE SAVOY - The variety most generally used in the East and especial ly throughout the South for shipping. Leaves large, round and thick, very much savoyed and rich deep green. One of the earliest varieties. Seed round.

KING OF DENMARK-A new and very popular variety. About as early as any and remaining in good condition from a week to two weeks after other varieties have gone to seed. The leaves are thick, stand well after cutting, and of a good quality.

\section{TOBACCO}

HAVANA-Pure Cuban grown seed. When grown in this country commands a high price as cigar stock. Pkt., 5ic; oz., 20c; 1/4-1b., $75 \mathrm{c}$

MISSOURI BROAD LEAF - A well known standard sort, valuable for cigar wrappers. Pkt., $5 \mathrm{c} ; \mathrm{Oz} ., 25 \mathrm{c} ; 1 / 4-1 \mathrm{~b} ., 75 \mathrm{c}$.

CONNECTICUT SEFD LEA F-Best adapted to the climate of the middle and northern states, as it is more hardy, and endures the cold better than the tender varieties grown south. Pkt., 5c; oz., 25c; 1/4-1b., 75c.

\section{TOMATO}

\section{Postpaitl.}

CULTURE-It is easy to grow tomatoes but as they require a long season it is best to start the plants in a green-house, hot bed or in the house. A cigar box kept in a sunny kitchen window will do. Sow the seed one-eighth to a quarter of an inch deep and keep the soil moist. As soon as the seedlings make a second pair of leaves transplant to another box or flat, keeping the plants four inches apart. When all danger of frost is over set the plants out in the garden.

NEW STONE-We call this king of the Livingstone kinds, which are the best types of large, smooth, solid "beefy" tomatoes; ripening evenly to the stem without a crack; exceedingly solid and firm-fleshed (as its name in. dicates); is an excellent shipper; quality the very best. Pkt., 5c; oz., 20c; $1 / 4$. lb. , $75 \mathrm{c} ; 1 \mathrm{lb} ., \$ 2.75$.

BONNY BEST-An early scarletfruited tomato which has proven a success all over the country. It is smooth, very even in size, very solid and also very prolific. Pkt., 5c; oz., 20c; $1 / 4 \quad l b . .75 \mathrm{c} ; 1$ lb., $\$ 2.75$.

"JOHN BAER" TOMATO-An early variety very much resembling Chalk Jewel but said to be two weeks earlier. Yields wonderful crops free from blight and rot. Bright red, and good flavor. Give them a trial. Per Pkt. $5 \mathrm{c} ; 07 ., 20 \mathrm{c} ; 1 / 4-1 \mathrm{~b} ., 75 \mathrm{c} ; 1 \mathrm{~b} ., \$ 2.75$.

GREATER BALTIMORE-This great tomato is well named. The color is a rich, cardinal red. The skin is so tough that it is a splendid shipper and keeper and is less liable to crack in wet weather than any other large tomato. Unsurpassed for market or for table use. The plant is a strong orower and is very productive, bearing with undiminished vigor until frost. The fruit is free from core, and the seed spaces are comparatively small. Pkt., 5c; oz., 20c; $1 / 4-1 b ., 75 c$ ! 1b., 
CHALK'S JEWLL-Vines vigorous, very productive, smooth, uniform in size and color, free from rot or cracking. Pkt., $5 \mathrm{c} ;$ oz., $20 \mathrm{c} ; 1 / 4-1 \mathrm{~b} ., 75 \mathrm{c} ; 1-1 \mathrm{~b} ., \$ 2.25$

EARLIANA TOMATO-This is the second season that we have made comparative tests of all early tomatoes, and are pleased to report that the Earliana variety, origin. al Sparks stock, produces fruit earlier than any other variey. The quality is good, of large, uniform size, red color. Is very solid. Fvery gardener will make good profit on early tomatoes when raising Earliana. Pkt., 5c; oz., 20c; 1/4-1b., 50c; 1-1b., $\$ 1.90$.

JUNE PINIK TOMATO-This new tomato resembles Spark's Earliana except in color, which is a fine pink color. It is the earliest pink Tomato grown, and is from 1 1/2 to 3 inches in diameter. The vines are very robust, almost blight-proof, and very heavy bearers, being the first on the market and lasts till frost. Pkt., 5c; oz., 15c; 1/4lb., $50 \mathrm{c}$.

YELLOW PLUM-Color, bright yeliow; excellent for preserving. Per pkt., 5c $1 / 2$-oz., $15 \mathrm{c}$; oz., $25 \mathrm{c} ; 1 / 4-1 \mathrm{~b} ., 75 \mathrm{c}$.

RED PLUM-Same as above, except color. Pkt., 5c; 1/2-oz., 15c; oz., 25c; 1/4-1b., 75c.

RED CHERRY - A small, early variety; size and shape of a cherry. Pkt., 5c; 1/2.0z., $15 \mathrm{c} ;$ Oz., $25 \mathrm{c} ; 1 / 4-1 \mathrm{~b} ., 75 \mathrm{c}$.

HUSIK TOMATO, or GROUND CHERRY-This is much liked by many for preserves and for eating from the hand; it makes also, good pies, and is very fine dried in sugar. Pkt., 5c; 1/2-oz., $15 \mathrm{c}$; oz., $25 \mathrm{c} ; 1 / 4-1 \mathrm{~b} ., 75 \mathrm{c}$.

\section{VINE PEACH}

The vine on which they are borne is somewhat similar to the muskmelon vine, and requires the same cultivation. The fruit is about the size of a large peach, ovalshaped, and of bright orange yellow color, somewhat russeted. For sweet pickles, pies or preserving they are superb. Pkt., $5 \mathrm{c}$; oz., $15 \mathrm{c}$; 1/2-1b., 50c; postpaid.

\section{TURNIPS}

One ounce will sow 100 to 150 feet of drill; 1 to $11 / 2$ pounds will sow an acre.

CULTURE-Turnips do best in highly enriched light sandy or gravelly soil; commence sowing the earliest varieties in April in drills from 12 to 15 inches apart, and thin out early to six or nine inches in rows. For a succession sow at intervals of a fortnight until the last week in July, from which time until the end of August sowing may be made for the fall and main crop. One ounce will sow 150 feet of drill; one and one-half pounds to the acre.

There is usually plenty of room in the garden during the fall months. Utilize this space by sowing Turnips. They are very easily stored and a nice supply of Turnips in the cellar or in a pit will help out mightily on the winter food bill.

Turnips also make excellent stock feed for fall and winter use. They are much liked by all stock and the feeding of turnips or rutabagas keeps them in good condition. We earnestly recommend farmers to sow turnips and rutabegas for this purpose. We know it is profitable.

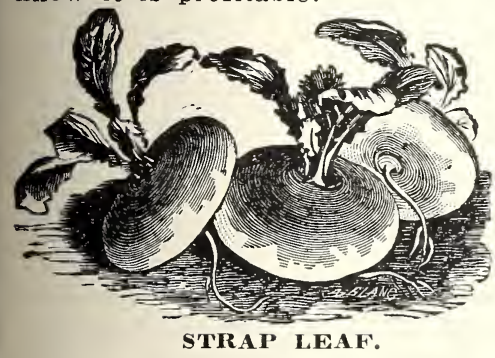

Pkt., ic; oz., 10c; 1/4-1b., 25e; 1-1b., 90c. Postpaid.

EARLY SNOWBALL-Is medium sized, pure white and early, of excellent quality. In our market it is much admired.

EARLY WHITE EGG-A quick-growing, egg-shaped, perfectly smooth, pure white variety, growing half out of the ground, with small top and rough leaves. Its smooth, white skin and quick growth make it particularly adapted for market purposes. The flesh is very sweet, firm and mild, never having the rank, strong taste of some varieties.

EXTRA EARLY PURPLE TOP MILAN-The earliest in cultivation. The bulb is very flat, of medium size, quite smooth, with bright purple top; leaves few, short and light of color, growing very compact, and making an exceedingly small and neat top, The pure white flesh is of the choicest quality, hard, solid and fine-grainel. It is an excellent keeper. Oz., $10 \mathrm{c} ; 1 / 4-1 \mathrm{~b} ., 35 \mathrm{c} ; 1-1 \mathrm{~b} ., \$ 1.00$.

PURPLE TOP (Strap Leaved). - The standard of this part of the country. Superior for early or late planting. Round, flat, good sized, small top with but few leaves; flesh very fine grained; flavor good. Pkt., $5 \mathrm{c} ; 0 \mathrm{z} ., 10 \mathrm{c} ; 1 / 4-1 \mathrm{~b} ., 25 \mathrm{c} ; 1 \mathrm{~b} ., 90 \mathrm{c}$.

AMBER GLOBE (Strap Lenved)-One of the best varieties, either forl table use or for field crop for stock. Flesh yellow, fine-grained, and sweet; color of skin yellow with green top. Hardy, keeps well, a good cropper, and grows to a very large size.

GOLDEN BALL-Undoubtedly among the most delicate and sweetest yellow-fleshed turnips yet introduced. Not of large size, but firm, hard and one of most excellent flavor. Keeps well, and is superior in its table qualities. Pkt., 5c; oz., 10c; 1/4-1b., 25c; 1b., $90 \mathrm{c}$.

PURPLE-TOP YRLLOW RUTABAGA-The best variety of Swedish turnip in cultivation. Hardy and productive; flesh vellow, of solid texture, sweet and well flavored; shape slightly oblong; terminates abruptly with no side or bottom roots; color deep green, with little or no neck. 


\section{VEGETABLE PLANTS}

Not Postpaid. See page 38 for Postage Rates.

We make a specialty of them.

Packed ready for shipment by express or mail. Weight, 1 Doz., 1 lb.; 100, 3 lbs.

EARLY CABBAGE-Wakefield and Winningstadt, (ready April 15th.) 75c per 100; $\$ 5.00$ for 1,000 .

LATE CABBAGE-Leading varieties (ready June 1st). $75 \mathrm{c}$ for $100 ; \$ 5.00$ for 1,000 CAULIFLOWER-Danish Snowball (ready April 15). $\$ 1.50$ for $100 ; \$ 10.00$ for 1,000 TOMATOES-From seed bed; leading varieties (ready May 1 ). $60 \mathrm{c}$ for $100 ; \$ 4.00$ for 1.000 . PEPPERS-Leading varieties (ready May 15). \$1.00 for 100. EGG PLANT-Transplanted (ready May 15). \$2.00 for 100.

CELERY-Leading varieties (ready June 15). $75 \mathrm{c}$ for $100 ; \$ 5.00$ for 1,000 .

\section{SWEET HERBS}

\section{Postpaid.}

CARAWAY (Carum-Carvi) - Chiefly cultivated for the seed, which is used in confectionery and medicine. Pkt., 5c; oz., 10c; 1/4-1b., 35.

CA'TNIP, or CATMIN'T (Nepeta Cataria)-Used as a medicinal herb, and also in befeeding. Pkt., 5c; oz., 30c.

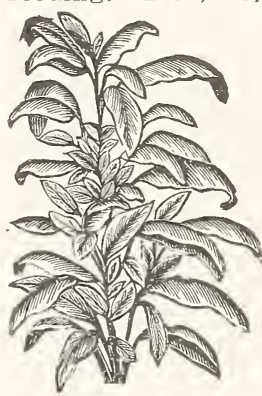

SA GE.

CORIANDER (Corlandrum Sativum)-Cultivated for garnishing but more frequently for its seeds, which are used by confectioners. Pkt., 5c; oz., 15c; 1/4-1b., 40c.

DILL (Anethum Gravelons) - The seeds have an aromatic odor and warm, pungent laste; they are used as a condiment, and also for pickling with cucumbers. Pkt. 5c; oz., $10 \mathrm{c} ; 1 / 4-1 \mathrm{~b} ., 30 \mathrm{c}$.

FENNEL, SWEET (Anethum Foeniculum) - The leaves, boiled enter into many fish sauces, and green, form a beautiful ornament. Pkt., 5c; oz., 15c; 1/4-1b., 40c.

HoARHOUND (Marrubium Vuigare-The leaves are used for seasoning and also in the manufacture of the popular cough remedy. Pkt., 5c; oz., 20c.

HAVENDER (Lavendula Spica) - It is cultivated for its fragrant flowers, which are used for distilling lavendar water. Leaves and flowers are aromatic. Gather the flowers before they begin to fade. Pkt., 5c; oz., 25c; $1 / 4-1 \mathrm{~b} ., 75 \mathrm{c}$.

MAJORAM, SUVEE'T (Origanum Majora)-Used for seasoning. Pkt., $5 \mathrm{c} ;$ oz., $15 \mathrm{c} ; 1 / 4-1 \mathrm{~b} ., 40 \mathrm{c}$.

ROSEMARY (Rosemarinus Officinalis) - A native of the south of Europe. It is used in many diseases quite successfully, among which are chlorosis and nervous headache. The tops only are used as medicine. Pkt., 5c; oz. 40c; 1/4-1b., $\$ 1.00$

SAFFRON-Pick the flowers, and dry, for their medicinal qualities. An annual. Pkt., $5 \mathrm{c}$; oz., $20 \mathrm{c}$.

SAGE (Salvia officinalis)-The most extensively used of all herbs for seasoning and dressing. Tea made from the leaves is an excellent sudorific. Perennial. Pkt., 5c; oz., $50 \mathrm{c}$

SUMMER SAVORY (Satureia Hortensis)-The leaves and flowers are used exten. sively for flavoring, particularly in soups and dressing. Pkt., 5c; 0z., 10c; 1/4-1b., 25c.

THYME, FRENCH (Thymus Vulgaris) - The leaves and young shoots are used for seasoning; a tea is also made for nervous headache. Pkt., $5 \mathrm{c}$; oz., $40 \mathrm{c}$.

WORMWOOD (Artemisa Absiathium) -Used medicinally, and is beneficial for poultry; should be planted in poultry yards. Pkt., 5c; oz., $15 \mathrm{c}^{\circ}$.

\section{FLOWER SEEDS}

ALL FLOWER SEEDS SFNT PREPAID ON RECEIPT OF PRICE.

The term "annual" is given to those plants which grow, flower, seed and die within the same year.

"Biennials" are those plants which do not generally flower until the second season and after blooming, die.

"Perennials" are those that do not generally flower until the second year, but continue to bloom for years and may be propigated by a division of the roots.

To have a beautiful flower garden, one must take pleasure in working and caring for the plants when young. It has ceased to be a necessity to keep such large stocks of bedding and other tender plants under glass through the winter thereby saving the expense of glass, fuel, labor, etc. We are enabled to send out the highest results of carefully selected seed, in neat paper packets, from which the amateur will derive his plants by means so simple as to be within the reach of everyone.

Nothing is more beautiful than the old-time and natural flowers. Do not cast aside the Single Petunias, Hollyhocks, Fox-gloves, Forget-Me-Nots and the old-time Phlox and Sweet William, for nothing is handsomer than the old-fiashioned flowers. Were We to assist nature more, rather than try to create monstrosities, our gardens would look by far more beautiful and natural.

The general rules for sowing Flower Seeds, as well as any other seeds, is to sow them at the proper depth; and the depth at which they are sown should in every instance be governed by the size of the seed itself. As the sprouts of small seeds are naturally small, if sown as deep as large seeds, they will be either unusually long in starting or more likely perish in the ground after sprouting, for want of sufficient strength in the young sprouts to force a passage through the soil. Very small seeds, such as Portulaca, Campanula, Digitalis, etc., should be merely sprinkled on the sur face of the ground after making it quite smooth with the back of a spade, and barely covered with finely sifted, light mellow soil, and afterward protected from the scorching sun and heavy rains by a cloth mat or some green branches stuck around it.

Another object to be considered is the soil into which the flower seeds are to be sown. The soil best adapted for flowering plants generally is a light, friable loam, containing a sufficient amount of sand to render it porous. A great many varieties will live in almost any kind of soil, except it be extremely dry, calcareous, or of a stiff 
heavy character; still to give them a fair chance for development, some little pains should be taken in adding to the soil as much as possible, what may be wanting in it. Deep digging and enriching with thoroughly decayed manure is the least that should be done. If the weather, after sowing, should be dry, it will be necessary to water the places where the seeds are sown with a fine rose watering pot, regularly, but slightly, every evening, as it is essential that the seeds during their process of germination should be kept constantly moist. From a neglect or oversight of this arise most of the failures. As the process of germination is often slow, the patience is sorely tried. We can assure our customers that there is no better flower seeds offered by any seed
house in America.

ADONIS-Plants with fine and graceful foliage, and brilliant scarlet flowers, remaining a long time in bloom; grows well in the shade, or under trees; height, one foot; hardy annual. Adonis aestivalis, pkt., $5 \mathrm{c}$.

ALYSSUM, SWEET-A favorite flower for bouquets; white, very fragrant, and producing a succession of bloom through the summer and until after severe frosts; always wanted when a bouquet is to be made; one foot; hardy annual. Pkt., 5c.

Alyssum, Martimum-Pkt., $5 \mathrm{c}$; Oz., $35 \mathrm{c}$.

Alyssum, Dwarf or Little Gem-Pkt., 5c; oz., $35 \mathrm{c}$.

ACROCLINIUM (Everlasting)-The Acroclinium is one of the most beautiful of everlasting flowers; it is of strong growth, and bears a great number of pink and white Daisy-like flowers, with yellow center; should be gathered the first day they open, before fully open to secure a beautiful center when dried; height, eighteen inches; half hardy annual. Per packet, 5c.

Acroclinium-Mixed colors; Pkt., 5c.

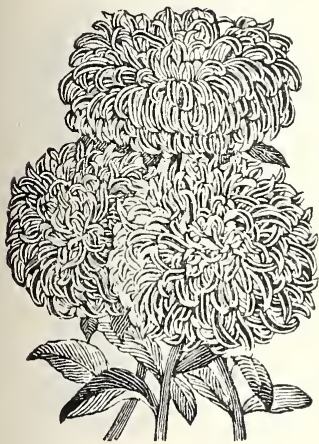

A STER.

AQUILFGIA, TRUE COLUMBINE (Rocky Mountain) Colorado's emblematic flower; needs to be seen to be appreciated. The flower petals lay open more flat than th common Columbine; color is a light blue; in very high altitudes nearly white. We are headquarters for this seed and furnish the true Aquilegia Coerules. Pkt., $5 \mathrm{c}$.

ASTERS-No family of plants bear such distinct marks of progress as the Aster, and none are more eagerly sought, an almost endless variety; always reliable. For best results sow seed early indoors, then transplant to open ground.

Comet or Branching-A handsome and very distinct variety, resembling Japanese 'Chrysanthemums; half dwarf; mixed including many colors. Pkt., $5 \mathrm{c}$.

German Quilled-This is the popular Japanese Needle, grows eighteen inches to twenty inches high, with thirty to forty flowers on long stems; our mixture includes white, rose, carmine, blue, etc. Pkt., 5c.

Lavender Gem-When first opened the flower is an exquisite shade of delicate lavender, deepening with age. The flowers always full double, looking like a beautifui large crysanthemum. Pkt., $5 \mathrm{c}$.

Giant Comet or Poodle Aster-The handsomest of the tall asters resembling Japanese crysanthemums. Mixed or in separate colors. White, red, pink, blue, and lavender. Per pkt., $5 \mathrm{c}$.

AMARANTHUS-Vialuable for its varieties of handsome foliage, whether grown in the conservatory or garden. The colors will be more brilliant if planted in moderately rich soil.

Amaranthus Caudatus-(Love Lies Bleeding)—-Well known, Pkt., 5c.

Amaranthus Tricolor-Leaves yellow, red and green; well known as Joseph's Coat; very showy in beds alone; hardy annual; two feet high. Per pkt., $5 \mathrm{c}$.

BALSAMS (Lady Slipper, Touch-Me-Not)-Magnificent conservatory or outdoor plants, producing their gorgeous masses of beautiful, brilliant-colored flowers in their greatest profusion. The soil should be of the richest possible character. Tender annuals.

Balsam, Double Tail-Fine mixed; a particularly fine strain of Balsam. Per pkt., $5 \mathrm{c}$.

$5 \mathrm{c}$.

Balsam, Dwarf Double-Grows only one foot high. Pkt.,

BRACHYCOME (Swan River Daisy)-Produces an abundance of daisy-like flowers about one foot high; fine for edg. ings, beds or rustic baskets; finest mixed. Per pkt., $5 \mathrm{c}$.

BACHELOR'S BUTYON-A showy annual, of easy culture, flowering freely with a great variety of color, in common garden soil; height, two feet. Pkt., $5 \mathrm{c}$.

CANDYTUFT-One of the most hardy annuals, almost equally so as Sweet Alyssum. Like it, is one of the earliest culture and grown for a variety of purposes almost all the year round; mixed. Per pkt., $5 \mathrm{c}$.

CANTERBURY BELLS-A' handsome perennial; with blue, white and rose-shaped flowers, remaining in bloom a long time; fine for bouquets; height, one foot; hardy biennial. Campanula medium, mixed colors, pkt., $5 \mathrm{c}$.

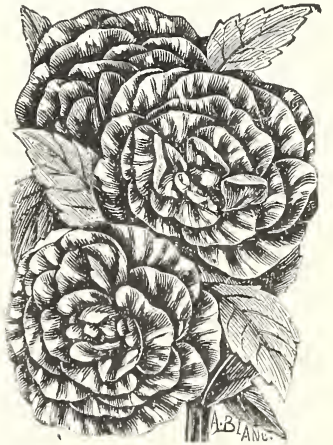

BALSAM. 


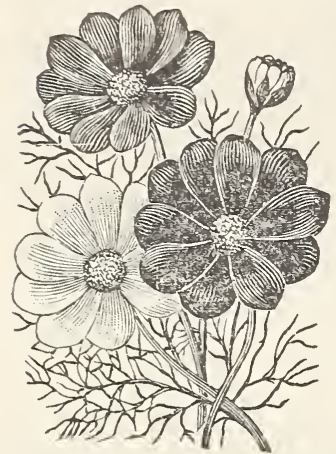

cosmos.

CANARY-BIRD FLOWER-One of the best climbing plants, with graceful foliage of a delicate shade of green with small yellow flowers, which when half expanded have a fanciful resemblance in shape of canary birds; height, eight feet; half hardy annual. Pkt., 5c.

CisTOR BEANS (Ricinus-A luxuriant expansive foliage plant of tropical appearance, that should have a place in every garden affording the requisite space. The stalks of the plant of this variety are of a brownish red; the leaves are very large, palmate and strikingly elegant; height, six to seven feet; tender annual.

Ricinus Sanguincus-Large red. Pkt., 5c; oz., $15 \mathrm{c}$

Ricinus Zanzibariensis-New Zanzibar; a giant; large-leaved variety. Pkt., $10 \mathrm{c}$; oz., $20 \mathrm{c}$.

CENTAUREA (Marguerite, Corn Flower)-A sweet scented Centaurea, about as large as a medium-sized Carnation. It is a sort from Centaurea Odorata, and the plants are about eighteen inches high. The flowers are beautifully lacinated and produced on long stems, their lasting quality after being cut is remarkable. The beauty of this easily cultivated annual is certainly to excite adrniration. Pkt., 5c.

CYPRESS VINE-One of the most beautiful of the climbers; fine delicate-cut foliage, dotted with small, scar. let, star-shaped flowers; for covering pillars, trellis work, etc., is not surpassed for grace and beauty; height, eight feet; tender annual; mixed colors. Pkt., 5c.

CARNATION - This beautiful and well-known flower produces a finer bloom when grown from seed than when grown from cuttings taken from old plants. This seed will produce a fine variety of colors, with flowers of good size and substance; height, eighteen inches; half hardy perennial.

German-Mixed colors. Pkt., $5 \mathrm{c}$.

Iarguerite-Blooms in four months from time of planting. Per pkt., $5 \mathrm{c}$

Cosios-Are unquestionably very handsome flowers, and it is astonishing how quickly they become general favorites. Only a few years ago they were practically unknown. There is but one objection to their giving general satisfaction, and that is their late flowering habit. The plants require a very long time to develop, and that brings their flowering seasons late in the fall. This objection will not be found in our "early flowering;" strain. Seed sown in the open ground in the beginning of May will produce blooming plants in August and they will continue to flower late in the fall. We know of no single flower that is as handsome and chaste as the Cosmos, while for keeping qualities they are unexcelled.

Farly Flowering-Mixed. Pkt., $5 \mathrm{c}$.

Giants of California-Mixed. Pkt., 5c.

CALIFORNIA POPPY (Eschscholizia)-A flower attractive in foliage, bud and bloom; one of the most brilliant

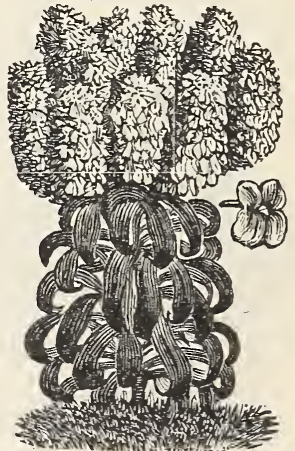

CANDY TUFT.

flowers grown; plants procumbent, forming dense, bushy masses with a succession of flowers from July until after severe frosts; when grown with Dwarf Convolvulus, contrasts finely with the dark blue; height, one foot; half hardy perennal. Eschscholtzia California, pkt., $5 \mathrm{c}$.

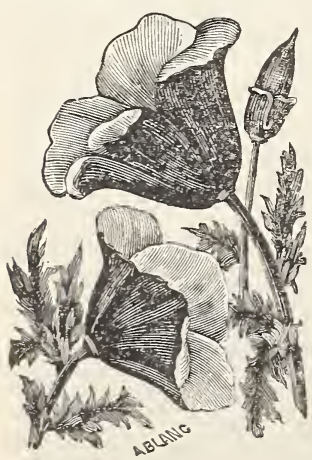

JALIFORNIA POPPY.

COXCOMB-Highly ornamental plants, producing crested heads of flowers somewhat resembling a cock's comb. There are many colors and shapes, but the scarlet and crimson ones are the most brilliant and rich. The oftener they are transplanted or shifted, the more beautiful they grow; height one to three feet; mixed colors Pkt. 5c.

CALLIOPSIS-A very showy plant, producing flowers in nearly every shade of yellow, orange, crimson, red and brown. If the seed pods are removed as fast as they appear, the plant will remain in bloom much longer; height, two feet, hardy: mixed colors. Plit., $5 \mathrm{c}$.

CHRYSANTHEMUM-The great and growing demand for the annual varieties has brought Chrysanthemums into general favor. The leading sort now grown for cut flowers at nearly all seasons is Burridganum, an exceedingly beautiful sort, the colors having the appearance of being laid on with a brush, and for this reason they are frequently called "painted daisies."

Chrysanthemum Coronarium-Double Mixed. Pkt., 5c.

MORNING GLORY (Convolvuius Major)-A handsome showy climber, of easy culture, suitable for covering arburs, windows, trellises, old stumps, etc., It is so perfectly hardy as to grow in almost any soil. Hardy annual; ten feet hign mixed packet, $5 \mathrm{c}$.

WILD CUCUMBIR-Will grow 30 feet in one season. Bears pretty, white fragrant flowers, followed by an abundance of ornamental and prickly seed pods. Packet, $5 \mathrm{c}$; ounce, $15 \mathrm{c}$.

DOUBLE DAISY-Charming little plants for edging and borders. The flowers are quilled and flat-petaled, white, pink, red and transplant to rich, cool, partially shaded situation; set the plants six inches apart; roots can be divided at any time; flowers are most abundant in spring; tender perennial; six inches high; double mixed; very fine. Pkt. $5 \mathrm{c}$.

DAISY-BURBANK'S GIANT SHASTA-Flowers very large and graceful; pure white, single and grow on long stiff, wiry stems. Packet $5 \mathrm{c}$. 
DIAN'THUS SINENSIS (Indian Pink)-This magnificent tribe is one of the most satisfactory that can be raised from seed. Dianthus Sinensis and varieties are known as Indian Pinks, perhaps one of the most beautiful classes of plants existing. Pkt., 5c.

Dianthus Chinese-Double, extra fine mixed; a mixture of the most beautiful double sorts, and of every desirable shade or peculiar marking. This will give a bed of beautiful flowers and scarcely two plants will be alike. Pkt., 5c.

FORGE'T-ME-NOTS (Myosotis)-The different varieties of this popular plant are very beautiful and too well known to need mentioning. They succeed best in moist situations.

Myosotis, Dwarf, Blue - A charming dwarf Forget-Me-Not, under eight inches in height, free growth, thriving well in either sunny or shady spots. Pkt., 5c. ed fruit; the vines are of rapid growth and with luxuriant foliage, adapted for covering screens, arbors, etc., height ten to twenty feet; tender annual.

All Kinds-Mixed ornamental. Pkt., 5c; oz., $15 \mathrm{c}$.

Dish Cloth, or Lufra-A rapid climber, having long, greer. fruit, the inside of which is a fibrous mass, which, when the shell and seeds are removed, makes an excellent substitute for a bath sponge. Pkt., 5c; oz., $25 \mathrm{c}$.

Dipper, or Siphon-Used for dippers. Pkt., 5c; oz., $25 \mathrm{c}$.

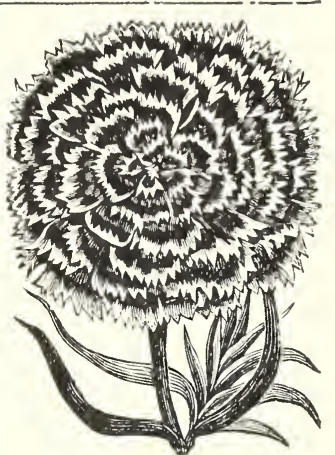

DIA NTHUS. or cold Pkt $5 \mathrm{c}$; Oz $25 \mathrm{c}$

GYPSOPHILA-Smäll, fragrant flowers, borne on long feathery stems. No flower adds more of light and grace to a bouquet than this, and when once grown will be found indispensable. In bloom through the summer from the first of July till frost.

Baby's Breath.- Pure white perennial. Pkt., 5c. in a remarkable degree; flowers large and densely double, remaining a long time in bloom. Is one of the best and most ornamental of the perennials, Height, five feet. Hollyhock, prize double mixed. Per pkt., 5'c.

LARKSPUR-The Larkspur is one of the handsomest and most useful of plants, and for large gardens is invaluable. The brilliancy of some of the colors is unsur. passed. Easily propagated by seed or by dividing the roots; delights in a deep, rich soil and should be sown in August or September. Larkspur, Dwarf German Rocket, double, extra fine mixed. Per pkt. $5 \mathrm{c}$

GILIA-Color, azure blue and light blue shaded with vellow and white. Pkt., 5c.

LANTANA-The varieties of the Lantana are almost numberless. The flowers are borne in Verbena-like heads, embracing every shade of pink, purple, orange and white. Finest French Hybrid, mixed, all colors. Per pkt., 5c.

LINUM-(Crimson Flax)-Linum grandiflorum rubrum. One of the most beautiful annuals known; valuable for bedding. Per pkt., $5 \mathrm{c}$.

LOBELIA - A most elegant and useful genius of plants of easy culture and well adapted for bedding, edging, pots or rockeries. They are applied as universally in general summer gardens as scarlet geraniums, to beds of which they form a neat and effecting edging. Seeds should be covered lightly. Lobella Brinus, mixed, pkt., 5c.

MARIGOLD-The marigold has been an inhabitant of the flower garden from time immemorial, and where a rich display of bloorn is desired is almost indispensible. The French varieties are tall, usually two feet or more, while the African are more dwarf, of most perfect form and gorgeous beauty; all are desirable. Hialf-hardy annual; bloom till frost.

Marigold, African, Double Dwarf-Very fine mixed. Per pkt., $5 \mathrm{c}$.

Mariold, French, Tall-Very fine mixed. Per pkt., $5 \mathrm{c}$.

MARVEL, OF PERU, or FoUR o'CLOCK-Old-fashioned, but none the less beautiful on that account. The plants are large and require four feet space; make a pretty hedge. Some of the varieties have beautifully variegated leaves. Will grow in any common garden soil, from seed sown in open ground. Hardy annual, two feet high. Hybrid, finest mixed. Per pkt., 5 c.

MIGONETTE-A well-known hardy annual, producing dense, semi-globular heads of exceedingly fragrant flowers borne on spikes three to six inches long. It is in bloom nearly the whole season and the perfume is so fragrant that the whole atmosphere around is perfumed. Pkt., 5c.

Reseda odorata-Large flowering variety. Per pkt., $5 \mathrm{c}$.

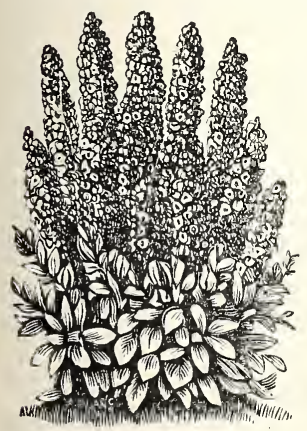

Migonette, Dwarf-Machet, dwarf. French variety, with broad spikes of very fragrant red flowers. Per pkt., 5 c.

MOONFLOWER - The true Moonflower is the most vigor ous of all the summer climbers; a single plant can easily be made to cover by August 15 th, a trellis thirty to fifty feet high and six feet broad, with a dense mass of leaves, studded every night or cloudy day with hundreds of beautiful white and wax. like flowers four to six inches in diameter. Height, thirty to fifty feet. Per pkt.

MOURNING BRIDE-One of the best flowers for bouquets; plants of dwarf habit, and compact; the flowers borne on long wiry stems. A great variety of colors, from white to very dark purple-almost black. In bloom from August till after severe frosts. Height, eighteen inches. Tender perennial. Scabiosa, dwarf double. Per pkt., 5c.

DWARF NASTURTIUM-A bed of Dwarf Nasturtium is very desirable for borders, along walks, etc. They are in constant bloom. Grow about one foot high. Mixed colors. Per pkt., $5 \mathrm{c}$; oz., $10 \mathrm{c} ; 1 / 4-1 \mathrm{~b} ., 30 \mathrm{c}$,

TALL NASTURTIUM-This well-known annual is one of the best for trellis and arbor decorations; flowers of a great variety of rich colors, striped and spotted with different shades is excellent for bases and baskets, also does finely when grown 
ers from the first of July until frost. Height, six feet. Mixed all colors. Per pkt., 5c. 1-oz., 10c; $1 / 4-1 \mathrm{~b} ., 30 \mathrm{c}$.

HETUNA-One of the best flowers for a splendid display through the entire season. Beautiful, new colors; striped and marked in the most diversified manner. The ease of culture, profuse and continuous bloom, adaptation for different styles of growth-indoors and in the garden render the Petunia one of the most valuable of the annuals and entitled to a generous share of the space in every garden. In bloom from the first of July to October.

Giants of California-Produce immense large single blossoms. Per pkt., $15 \mathrm{c}$

Striped and Blotched-Single, mixed. Per pkt., 5c.

POPPI-Hardy annual of quick growth and producing large, brilliant colored flowers, growing freely in any garden. Produces a fine effect in clumps or beds.

Double Carnation Flowered-Mixed, Per pkt., $5 \mathrm{c}$

Paeony Flowered-Flowers in size equal to paeonies mixed. Pkt., $5 \mathrm{c}$; oz., $15 \mathrm{c}$.

Oriental Perennial Poppy-Immense flowers of brilliant colors. Will bloom for years without reseeding. TRY IT. Pkt., 5c.

\section{SWEET PEAS}

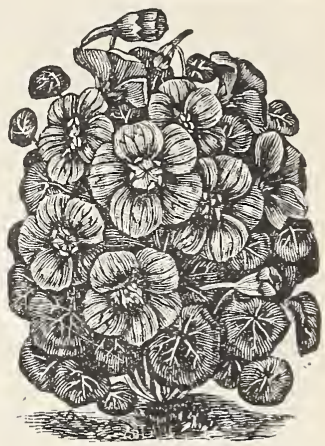

NASTURTIUM.

We are headquarters for strictly high grade Sweet Pea seed. Our growers give special attention to selecting and cleaning. We have trade from all parts of the United States for our "selected strains," which are furnished at prices within the reach of all and as low as the ordinary stocks are priced by many.

GIANT OF CALIFORNIA - A very choice mixture of the leading varieties;oz., 10c; $2 \mathrm{oz}$.

$15 ; 1 / 4-1 b ., 25 \mathrm{c} ; 1$ ib., $90 \mathrm{c}$.

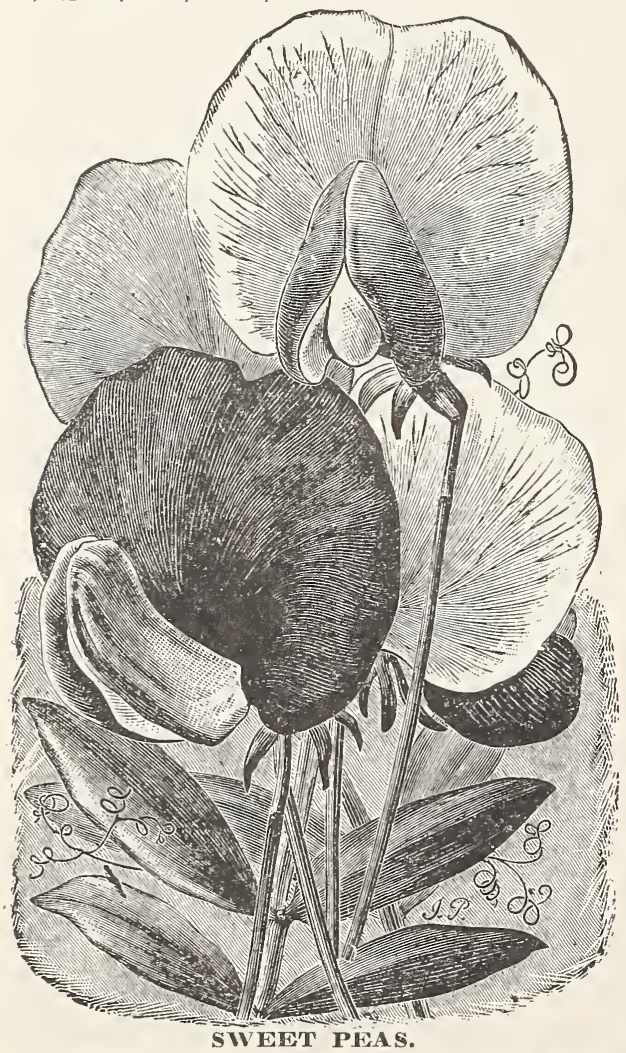

LVENDER-New Countess-Delicate lavender, the finest in this color. Princess May-Light shade lavender. Coun= tess of Radnor-Plain mauve; very charming. Lady Grisel Hamilton-Very large, with long stems.

BLUE-Captain of the Blues-Bright purple blue. Butterfly-White laced with lavender. Burpee's Navy Blue-The large flowers are of a richer violet purple with effects of a dark navy blue.

VARIGATED-Gray Friar- Watered purple on white ground. Aurora-Very large flaked orange-salmon. Mrs. Ioseph Chamberlain-White striped with bright rose carmine; very novel.

TRICOLOR-Captain Clark- White and lavender streaked ith carmine.

IAROON-Boreatton-The darkest and richest colored. Momarch-Deep bronzy maroon and dark blue.

WHITE-Emily Hendezson- A persistent bloomer. Blanche Burpee-A splendid pure white variety.

PINK-Lady Marie Currie-Fine orange pink, splendid cutting. Katherine Tracy-A soft but brilliant pink. Lovely-1 delicate shell tinged with yellow, often four flowers on a stem. Venus-A soft shade of rose, pink and buff. Apple Blossom-Bright rose and pink. Prima Donna-A lovely shade of soft pink.

PINK AND WHITE-Early Blanche Ferry-This is the standard among florists, as it has no rival for forcing. Painted Lady-The old favorite of pink and white.

RoSE- Her Majesty-Large hooded flowers. The Queen-Rose pink, wings mauve

SCARLET-Salopian- Very bright scarlet with large flower. CardinalIntense crimson scarlet. Mars- A large and well-formed scarlet. FireFly-A fiery shade of brilliant scarlet.

YELLOW-Primrose-Pale primrose yellow. Mrs. Eckford - Beautifully shaded: very vigorous grower.

SPENCER'S CELEBRATED MAMMOTH OROHID SWEET PEAS-These are the largest and highest colored of all the sweet pea family. They are simply beautiful; mixed colors. All Spencer Sweet Peas, pkt., 5c; oz., 15c; 1/4-1b., 50c; 1b., \$1.50. Postpaid.

RED, WHITE AND BLUF MIXURE-Consists of Salopian, Blanche Burpee, and Navy Blue in a mixture. Very novel. Try an ounce at least. Oz., 10c; 2-0z., 15c; $1 / 4-1 b_{.}, 25 c$

MIXED-Eckford's Hybrids-Mixed; nothing better in mixture of varieties and should not be compared with ordinary mixtures on the market. We mix in all our named varieties. Per oz., $10 \mathrm{c} ; 2-0 \mathrm{z}$, $15 \mathrm{c} ; 1 / 4-1 \mathrm{~b} ., 25 \mathrm{c} ; 1-1 \mathrm{~b} ., 90 \mathrm{c}$. 


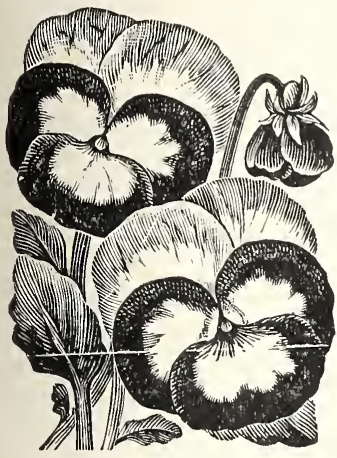

PANSY.

PANSY-These lovely flowers are favorites with all, not only for the modest brilliancy and variety of their colors, but for the durability of their bloom.

Trimardeau-Very large flowered, mixed. An entirely distinct and beautiful race with flowers of the richest and most varied shades of color. Plants of vigorous, compact growth. The flowers which possess unusual substance and consistency are each marked with three large blotches or spots. Per pkt., 5c.

Good Nixed Pansy-Consisting of many popular colors of ordinary strains. Per pkt. $5 \mathrm{c}$.

German Imperial Mixture-While the giant flowered are great favorites they do not carry all the shades and colors which are found in our German Mixture. This is the florist's popular strain. Mixed, a fine assortment. Per pkt., 5c.

\section{GIANT PANSIES}

GIANT OF CALIFORNIA-Mixed all shades $5 \mathrm{c}$ pkt.

CARDINAL-The finest bright red pansy. Very showy. Pkt., 5c.

LIGH'T BLUE-A delicate shade. Pkt., $5 \mathrm{c}$.

SNOWFLAKE-Large Satiny, pure white flowers. Pkt., 5c.

PORTULACA-Beautiful and popular hardy annuals of the easiest culture, luxuriating in an exposed, sunny situation and producing throughout the summer their flowers of almost every hue in the gravest profusion. The double Portulaca is one of the finest annuals in cultivation. Six inches high. Per pkt., $5 \mathrm{c}$.

PHLOX DRUMMONDI-Phlox Drummondii is one of the very finest of annual plants and stands almost unrivaled for profusion of color. The seeds can be planted in open ground in autumn or spring or plants may be started in a hot-bed and transplanted. Give good, rich ground and set plants six inches apart each way. Hardy annual one foot high. Pkt., $5 \mathrm{c}$.

SALPIGLOSsIS-Highly ornamental autumn flowering plants, with beautifully veined and tinted, funnel-shaped flowers. A very choice annual, two and one-half feet; fine mixture of flowering varieties. Salpiglossis Hybrid, extra fine mixture. Per pkt., 5c.

SWEET WILLIAM-The improved varieties of this popular flower are very beautiful and should find a place in every garden. A great variety of rich colors, eyes and variegated with other shades, forming large trusses of bloom, remaining a long time in perfection. A bed of Sweet William is very attractive the last of June and first of Ju'ly, at a time when but few other flowers are in bloom. Hardy perennial. Height, eighteen inches.

Dianthus Barbatus-Single mixed. Per pkt., 5c.

Dianthus Barbatus-Double mixed. Per pkt., 5c.

SMILAX-Sow in shallow boxes in light soil at any season of the year. Press the seed evenly into the soil and then cover to the depth of one-sixteenth of an inch. The seed often germinate slowly, lying sometimes three or four months before it all comes up. When fit/to handle, transplant into shallow boxes or small pots. Per pkt., 5c.

STOCKS (Gilliflower) - To have them bloom early start in hot-bed and transplant when small into pots and turn out in June to open border. iThey will blossom late in the season if planted in open ground. Hardy annual; one foot high. Stocks, German, ten weeks; double, very fine mixed. Per pkt., $5 \mathrm{c}$.

"WILD FLOWER GARDEN" or Mixture of all kinds of flower seeds. - Anyone who has planted and cultivated flowers in neatly laid out beds and borders is aware of the labor and constant attention required to produce the desired effect. To those who can not give it this care, the "Wild Flower Garden" presents a substitute which, for its unusual and varied effects, cheapness and the small amount of labor necessary for its construction, has no equal. The seeds we offer for the "Wlid Flower Garden" are a mixture of over 150 different varieties, and being mixed, can be offered at a much less price than when sold in separate packets. No one, not having such a bed, can form an idea of its beauty, the different seasons of bloom insuring something new almost every day. Pkt., $5 \mathrm{c}$.

VERBENA-For masses in beds on the lawn no plant excels the Verbena. In the varieties may be found every color, except yellow. If sown in the open ground in May they will bloom in August, but if started in the house in pots in winter, they will bloom sooner. Seed should be soaked in luke-warm water before planting, and care should be taken that the soil should be very rich. Verbenas can be grown from cultings, but seedlings are more vigorous and produce more and larger flowers. Half hardy perennial trailer. Mixed, per pkt., 5c.

ZINNIAS-Very showy plants, with large, double imbricated flowers, which when fully expanded, might easily be mistaken for dwarf dahlias. There is much satisfaction in a bed of Zinnias, for when nearly every other flower has been killed by frost this plant is still in full bloom. Few flowers are more easily grown or bloom more abundantly throughout the season. Sow the seed early in spring in open ground and transplant to one and one-half feet apart in good rich soil. "Half hardy annual; about eighteen inches high; mixed. Per pkt.p $5 \mathrm{c}$. 


\section{SUMMER FLOWERING BULBS}

\section{DAHLIAS}

Dahlias should be in every garden. They are easily grown and bear flowers of wonderful size and beauty. Order a few of the new Dahlias.

\section{NOVELTY DAHLIAS}

A few of the best of the new varieties. These have long stems and are excellent for cutting.

CULTURE-Dahiias are not particular as to the soil or location, although maximum growth and bloom reward the full sun, some of the stronger sorts develop most perfect specimens in partial shade. Prepare the soil thoroughly by digging. Be moderate in the use of both manure and water. Never plant when soil is wet. Lay tuber on side; eye up, four inches deep, pressing soil firmly on tuber. Keep soil loose and mellow by frequent hoeing, drawing the soil to a slight hillock around the plant.

\section{CACTUS DAHLIAS}

The greatest and most phenomenal type of all dahlias showing the most remarkable development.

We have selected only the most popular and easy growing bulbs, which are sure to give satisfaction. The prices are exceedingly low for the first-class bulbs we have to offer. They will be sent prepaid.

20 c Each.
2 for $35 c$
6 for $75 c$
9 for $\$ 1.00$
12 assorted for $\$ 1.25$
Post Paid.

\section{CACTUS DAHLIAS}

1. FLORADORA-Deep rich wine color, long stem.

2. QUEEN OF HEARTS-Pure white.

\section{DECORATIVE DAHLIAS}

3. BLACK BEAUTY-Deep velvety, maroon color.

4. HORTULANUS-Pure snow-white. Elegant.

5. LUMIERE-Ground color, white suffused towards the ends of petals with red.

6. CASSATT-A rose pink, large size and extra good bloomer.

7. SOUVENIR DOAZON-A large lovely shade of orange red.

8. POM PON-A pure white round snow-ball shape.

9. JACK ROSE-Crimson red, with maroon shadings.

\section{PAEONIES}

60c Each. Postpaid.

This grand old favorite is to-day one of the grandest perennial flowers grown. The colors are in great variety. The blooms are in greatest profusion. Among the varieties are white, pink, crimson, etc.

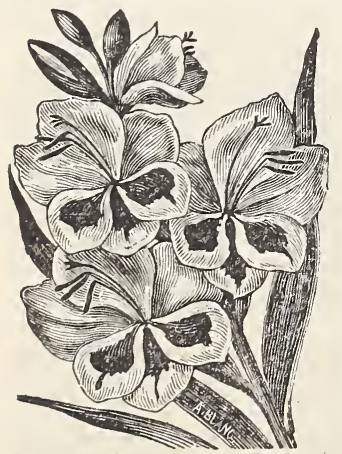

GLADIOLI.

FESTIVA MAXIMA-The grandest of all Paeonies. White with carmine flaked center and very double.

\section{EARLY RED-One that blooms before Decoration Day.}

EARLY WHITE-Same as above, only pure white.

EARLY ROSE-An early pink, blooms in clusters, very fragrant.

\section{GLADIOLI}

No flower has gained more rapidly in the public favor; it is easy to cultivate and almost sure to bloom. Thrives in almost any soil. In autumn, take up, dry and keep from frost. We have made up a strictly "high-grade mixture" which comprises many named varieties, including some of Lemoine's Seedings. All large size bulbs $5 \mathrm{c}$ each; $50 \mathrm{c}$ per 12. 


\section{TUBEROSES.}

Every lover of flowers admires the Tuberose. We make a study to procure none but the pure dwarf variety of large spikes. Double Excelsior Pearl Dwarf. First size bulbs, 7c each: doz., 70c.

\section{CANNAS.}

A rival for the Dahlia, in many respects, with its large tropical foliage, bronze and green, and its large beautiful many colored Howers, of different types and forms. In bloom from July till October, it deserves a place in every flower garden. Plant in good, well drained soil as soon as danger from frost is over.

$$
\text { a0c each; } \$ 2.25 \text { per 12, postpaid. }
$$

Alsace-Flowers creamy white, green foliage.

Duke Marlborough-Rich maroon, green foliage.

Egandale-Currant red, bronze foliage.

foliage.

David Harum-Large vermiilion flowers, dotted with crimson spots, bronze

Shenandoah-Large salmon colored flowers, bronze foliage.

King Humbert-Bronze leaf and immense scarlet flowers.

BLEEDING HEART-Tuberous-rooted plants that bloom in the spring, favorably known almost everywhere. They require only the ordinary culture of border plants. Roots should be divided every third year. The flowers are delicate pink, very graceful, produced continuously from May to July, 50c.

MADERIA VINE_Tuberous-rooted climber with glossy green leaves and delightfully fragrant, white blossoms. Sometimes called Migonette vine. It is of rapid growth and from a few tuber vines will be produced sufficient to cover one side of a cottage in a single season. The tubers are tender and must be protected from frost during winter. Each $25 \mathrm{c}$.

\section{SPRING FLOWERING BULBS FOR FALL PLANTING}

Calla Lily, white.

Roman Hyacinth, white.

Single Hyacinth, mixed colors.

Single Tulips, $\mathrm{m}$ ix ed colors.
Double Tulips, mixed Narcissus.

colors.

Crocus, mixed colors.

Lily of the Valley.

Chinese sacred Lily.
Freesai.

Oxalis.

Snowdrops, single.

Snowdrops, double.

The above named Bulbs are for Fall Planting and cannot be furnished in the Spring. We can only ship them during the Fall and early Winter Months.

\section{PRICE LIST OF GRASS AND FIELD SEEDS}

\section{Write for prices on large orders. See page 38 for postage rates. \\ Prices subject to fluctuations. Price on application.}

We pay particular attention to this department of our business. These seeds are selected with special reference to their quality. Purchasers may rely upon our best exertions to furnish grass and field seeds fresh, pure and free from noxious and foreign seeds.

\section{As Prices Fluctuate, Please Write for Prices.}

\section{Alfalfa.}

Clover, Mammoth Red.

Clover, Alsike.

Clover, White Dutch.

Clover, Sweet.

Bromus Inermus.

Lawn Grass. Cn'l P'k.

Blue Grass, English.

Pasture Grass, dry l'nd.

Pasture Grass, wet l'nd.

Blue Grass, Kentucky.

Orchard Grass.

Timothy.
Rye Grass, Italian.

Rye Grass, Perennial

Red Top, Fancy, H'ld.

Millet, Common.

Buckwheat, Silver Hull

Corn, White Kaffir.

Corn, Red Kaffir

Corn, Broom

Milo Maize.

Dwarf Essex Rape

Sorghum, Amber Minn.

Beans, Navy

Beans, Mexican.
Beans, Pink Eye.

Oats, White Russian

Rye.

Rye, Winter.

Hemp Seed.

Canary seed.

Peanuts.

Flax Seed.

Sand, or Hairy Vetches.

Canadian Field Peas.

Sudan Grass.

Feterita. 


\section{DESCRIPTION GRASS AND FIELD SEEDS.}

EXTRA FINE LAWN GRASS-The essentials for a fine lawn are: First, a rich, well-drained soil; second, careful preparations of the ground making it as fine and smooth and mellow as possible; third, a wise selection of seeds; fourth, sowing at such a time as to give the young plants a chance to become well established before being submitted to very dry or cold weather or to the direct rays of the hot summer sun. However much care is bestowed on the soil and seed no lawn will be beautiful without frequent mowing and rolling. Too much care cannot be bestowed upon the selection of the grasses, as some varieties are more luxuriant in spring, others in summer, others again in autumn, and a combination of the proper sorts is required for a perfect, carpet-like lawn. We have given much thought and made many experiments to secure the best selections and think our Central Park Mixture is the best possible for permanent lawns. It may be planted early in the spring or fall and should be sown at the rate of sixty to one hundred pounds per acre; much more is required than for hay or pasturage. If sown in the spring, sow as early as possible, making the surface very fine and smooth; then raking it over and sowing seed just before a rain, which if the surface has just been raked, will cover sufficiently. If the expected rain does not come, cover by rolling with a light roller. For fall seeding, sow before the autumn rains, and early enough to enable the young grass to become well established and before very cold weather, when a light dressing of manure should be given. One pound of this seed is sufficient to sow 200 square feet.

THE SILO - Now is the time to build a Silo. When a five-acre patch of corn will fill a hundred-ton silo with special feed one cannot afford to buy hay at $\$ 10.00$ per ton.

We carry the best and fullest line of Silo Corn that can be found anywhere in the West.

SUDAN GRASS-Another season has fully demonstrated the fact that Sudan Grass for making hay is the wonder of the age. Just think of a grass standing thick and heavy, furnished with an abundance of broad blades, growing during the past dry season, in a section where there was only one light shower after the grass was up, five feet high for first cutting, and three feet for second cutting, and making a yield of over five tons per acre, where all other crops were a total failure. Think of a grass that with irrigation, made a growth for first cutting of seven to eight feet, and of second cutting of from three to four feet, making a yield of seven to eight tons per acre of hay equal to Timothy.

Think of a grass that a single seed will produce from 100 to 150 stocks of good hay, then combine all these good qualities, and you have some idea of the value of this great forage plant.

We are headquarters for pure northern grown seed.

PERENNIAL RYE GRASS-(English Rye Grass.)-A nutritious, permanent grass for meadows and pastures, or for mixing with other grasses for lawns. It is also well adapted for permanent meadows and yields large quantities of very nutritious hay. It makes a quicker, leafier growth than most other grasses, succeds in the shade as well as in the open. Sow in spring and fall at the rate of 20 to 30 lbs. per acre.

RAPE, DWARF ESSEX, FOR SOWING-There is but one variety of Rape that has proven profitable to sow in America, and that is the Dwarf Essex. Do not be deluded into buying inferior grades offered by unscrupulous dealers through exaggerated advertisements. Such seed is often more or less mixed with the annual variety, which is not only worthless as forage, but once planted, is likely to become a pernicious weed. There is no plant that will give as heavy yield of forage at such small cost as this, and its general cultivation would add largely to the profits of American farms. Especially valuable for green manuring and pasture.

ORCHARD GRASS-No farmer should be without a small field of orchard grass, as in many respects it is superior to other grasses. It stands the drought, grows well in the shade, does well in wet or poor ground, and is splendid to prevent wornout fields from washing. This grass furnishes excellent pasturage three weeks before any other, and after close grazing ten days' rest is sufficient for another growth. Cows fed on this will produce more and richer milk than on blue grass. It makes a very heavy sod and when well set remains for many years. It is especially adapted for winter grazing, as it remains green all season. Sow 20 to 25 pounds an acre. 
SPRING RYE-We consider this one of the most valuable grains for spring planting. It does much better on Dry Farms than Spring Wheat and can be used for hay or grain. If irrigated it can be pastured for several weeks and then make a crop of grain. It is very hardy, standing extreme cold and drought better than any other grain.

RED KAFFIR CORN-This grows taller than the white; the stalks are slendered, but more juicy and very leafy. The heads are long, slender, compact and grow erect. They measure from one to two feet. The seed is red, smaller than that of the white, and rather hard and brittle. It does well on poor land and yields well. It ripens a little earlier than the white variety, and yields much heavier.

WHITE IKAFFIR CORN-It grows from four to five feet high, making a straight, upright growth. It has a stocky stem, with enormous wide leaves. The stalks keep green and are brittle and juicy, not hardening like other varieties of sorghum, making: excellent fodder, either green or dried, which is highly relished by cattle and horses. The seed heads form at the top of each stalk, and as soon as these show the grain well the joints next below the top send up shoots which yield the second seed heads. For the grain sow in rows three feet apart.

SORGHUM SUGAR CANE, EARLY AMBER-Its early maturity adapts it to almost every section. It has given entire satisfaction wherever introduced as a profitable crop. for fodder as well as for syrup making. It usually grows eleven to twelve feet high and stands well. If planted the first week in May the seed almost invariably ripens, thus giving a double crop each year, yielding twenty to thirty bushels of seed and 140 to 175 gallons of syrup to the acre.

FETERITA - We wish to call your attention to the Non-Saccharine Sorgum Feteria. This variety is from twenty to thirty days earlier than any of the ohers. It has been known to yield a heavy crop without a drop of rain. It yields from 60 to 80 bushels of grain and 3 to 4 tons of forage per acre. It takes from 3 to 5 pounds of seed per acre.

MILLET-The seed is very rich and thus specially valuable as a hog food. A very much-prized peculiarity of this millet is that the seed ripens while the stem is yet green, thus if cut promptly, can be threshed for the seed, while the hay, after being threshed, will make excellent fodder. Sow same as other millet.

RED TOP-A valuable grass for moist soils. It is a good permanent grass, standing our climate as well as any other, and consequently, well suited to our pastures, in which it should feed close, for if allowed to grow up to seed, the cattle refuse it. On moist, rich soil it will grow two feet and on poor, gravelly soil about half that height. It has been grown successfully even on "alkali" bottom lands, where other grass failed. Sow twenty or thirty pounds to the acre.

\section{INSECT DESTRO YERS.}

TOBACCO DUST-Kills all kinds of bugs and lice on cabbage, cauliflower, fruit trees, etc. Per pound, 15 cents; 10 lbs., $\$ 1.00$. Postage extra.

ARSENATE OF LEAD-Use wisdom. Don't have wormy fruit. It is neither good to look at nor is it good to eat and it always has to be sold at a sacrifice. The only way to destroy the worms effectually is to use Arsenate of Lead. It is the surest and best poison known. Requires no preparation and does the work. Write for prices.

IIME AND SULPHER.

BLACK LEAF 40 .

\section{CHICKEN FOOD}

\section{WRITE FOR PRICES}

For Postage Rates on all articles on this page, see page 35 .

Millet for Little Chicks. Meat Scraps. Ground Bone.
Ground Oyster Shell.

Mica Crystal Grit.

Cayenne Pepper.

\section{CALF MEAL}

Sell your milk and raise your calf on Calf Meal.

Your milk will bring several times the cost of raising a Calf on Calf Meal. 25 1b. Bag, \$1.75-Postage Extra. 


\section{POULTRY REMEDIES}

CONKEY'S POULTRY TONIC-Packages, $30 \mathrm{c}$ and $60 \mathrm{c} ; 25$ pound buckets, $\$ 3.50$. CONKEY'S LICE POWDER-Package, $15 \mathrm{c}, 30 \mathrm{c}$, and $60 \mathrm{c}$.

CONIEY'S NOX-I-CIDE-I quart, $80 \mathrm{c} ; 2$ quarts, $\$ 1.30 ; 1$ gallon, $\$ 2.00$.

CONKEY'S NOX-Per package, 6 cubs, $25 \mathrm{c}$.

CONKEY'S STOCK TONIC-Large Package, $60 \mathrm{c}$.

CONKEY'S BUTTER MILK-Starting feed for baby chicks, 25c, 40c, 75c.

CONIEY'S GROWING MASH-25c, $\$ 1.65$.

CONKEY'S ROUP CURE-Per box, $30 \mathrm{c}$ and $60 \mathrm{c}$., sizes.

CONKEY'S FLY KNOCKER-1 quart, 60c; 2 quarts, $90 \mathrm{c} ; 1$ gallon, $\$ 1.50$.

ANTI-FO LICE POWDER-1 pound cans, 25c; $21 / 4$ pound cans, $50 \mathrm{c}$.

ANTI-FO ANT POWDER-Per can, $15 \mathrm{c}$.

ANTI-FO STOCK TONIC-25 pound pails, $\$ 1.50$.

PRATT'S ROUP CURE-Per box, $30 \mathrm{c}$ and $60 \mathrm{c}$, sizes.

PRATT'S LICE POWDER-30c and $60 \mathrm{c}$, sizes.

PRATT'S REGULATOR-30c and $60 \mathrm{c}$ sizes.

CALF MEAL-Owing to the scarcity and high price of milk for raising calves, one of our leading chemists has devised a Calf Food which can be used in place of milk after the calf is a few days old, and it is much cheaper and a perfect success. Many of our dairymen are using it exclusively. We furnish circular on application. Per lb., 10c; per $25 \mathrm{lbs} ., \$ 1.75$; per $100 \mathrm{lbs} ., \$ 6.50$. Postage Extra.

HAND PLANTERS-For planting corn, beans and Kaffir corn. ACME- Works in any soil; has flexible and adjustable iron drop; it has an iron seed box and iron channel. The foot is made of steel; it is well made strong, durable, reliable, and gives universal satisfaction. Price \$1.75, Postpaid.

\section{IMPLEMENTS}

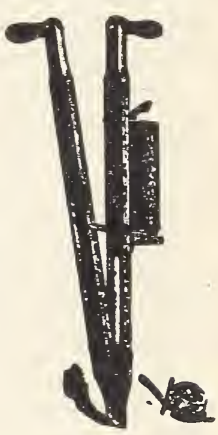

For Postage Rates on all articles on this page see page 38 .

STEEL TROWELS-Is of one solid piece of steel, and will outwear several of the ordinary sorts. No. 3090, 6-inch extra heavy, $20 \mathrm{c}$ each.

Bearing-Machined Steel Bearing Bolt with Counterbored Hub; Packed with Grease Prevents Dirt and Sand Getting in Bearing, Which Would Eventually Cause Wheel to Run Unsteady; and in Short Time Make Cultivator Almost Useless; Combines Three Tools in One and Has this Very Marked Advantage Over the Ordinary Type of Cultivator - You Can't Lose the Attachments Because they are Permanertly Attached to the Frame, and you Don't Have to Look for a Wrench. A Few Turns of the Hand Wheel Releases One Set of Tools and Allows Another to be Revolved into Working Position and Locked Securely in Place.

other Features-W $\mathrm{h}$ e e l h a s

Oval Steel Spokes Instead of

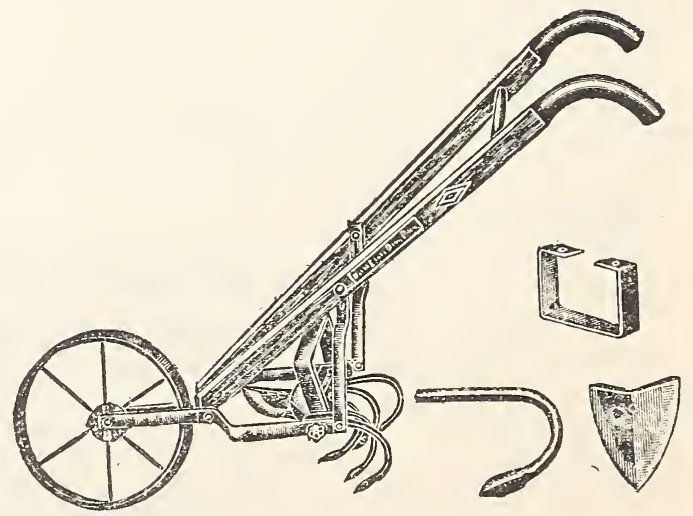

Ordinary Wire; Handles are of Varnished Oak with Bent Plow Handle Grips.

No. DEG 2-Beautifully Finished in Attractive Combination of Yellow, Red, Gray and Black; Diameter of Wheel 14 inches; Length Over all 53 inches; Handles Adjustable to Different Heights Height Over all 38 inches; Weight Each 20 ibs.........\$8.00 One in a Crate 


\section{SANITARY DRINKING FOUNTAINS}

We carry a full line of Sanitary Drinking Fountains for Chickens, These are so constructed that Chickens cannot get into the water and dirty it, and also keep the little chicks from getting in and drowning. They are made of galvanized Iron Send for one of these and you will be surprised at the labor it will save you, besides keeping the drinking water for your Chickens pure.

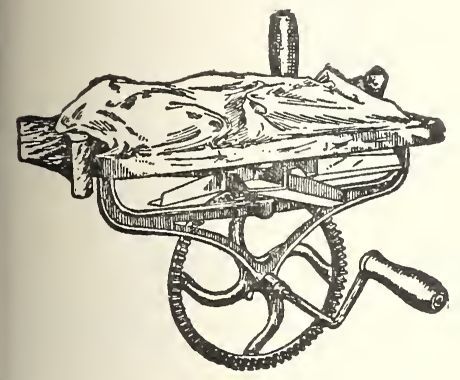

CYCLONE HROADCAS'T SEED SOWER.

CICIONE HROADCAST SEED SOWER-The frame of the machine which carries all the bearing parts is made of one piece of metal, thus assuring permanent alignment. This feature makes the Premier the easiest running machine on the market, and prevents it from getting out of order. The seed is fed to the fan wheel through an adjustable slide, in such a manner as to insure an even distribution. The siide can be closed instantly. The grain bag is supported by a strop across the shoulders. The Premier will sow any seed that is sown broadcast, such as oats, wheat, rye, barley, rice, flax, millet, clover.

Price, \$2.50.

\section{BIRDS AND BIRD SUPPLIES}

NOT POSTPAID

Canary birds are priced according to singing qualities. Our best male singers sell at, each ................... $\$ 10.00$

Females, each .......................... 3.00

Love birds, per pair ................ 10.00

Java Sparrows, each …............. 6.00 .

Gold Fish, by Express only,

each

Cages, from

Best mixed seed, 1b. ............... $\$ .25$

Bird Sand 3 lb. pkg. .................... .25
Heinp, 1b. …............................ .25

Rape, lb. ................................... .25

Nillet, 1b. ................................... .20

Canary seed, lb. ............................. .25

Bird Lettuce, lb. ............................ .25

Lice Powder, box ....................... .15

Wire Nests, each .................... .15

Bath Dishes, each ...................... .15

Seed and Water Cups, each ....... .15

Cage Springs and Chain, each .... .35

Bird Manna, each ....................... .15 
HAYES SPRAYERS

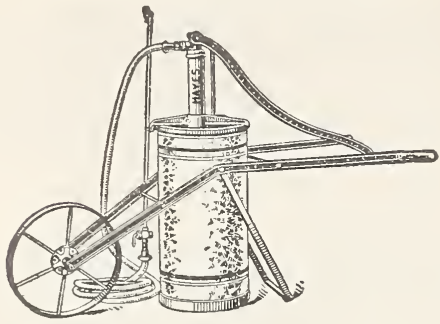

No. $1721 \mathrm{~F}$

\section{Wheelbarrow Sprayer}

Capacity $121 / 2$ gal., $32 \times 21 / 4$ pump, heavy galvanized steel banded tank. twin paddle which passes both sides of strainer and stirs liquid thoroughly, brass gauge, strainer of large capacity, complete with $12 \frac{1}{2}$ ft. of $1 / 2$-in. 5 ply spray hose and $8 \mathrm{ft}$. steel extension.

1 in crate, 75 lbs.

F. O. B. Provo, each

$\$ 29.50$

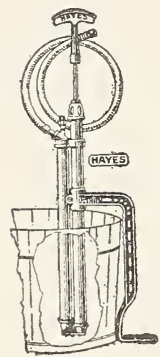

\section{Bucket Spray}

$18 \times 1$, double cylinder, length over all 27-in., all working parts brass, bronze ball valves, malleable iron foot rest.

$$
\begin{aligned}
& 2 \mathrm{H} 7743 \\
& \text { carton, } 71 \frac{1}{2} \mathrm{ibs} .
\end{aligned}
$$

Each, $\$ 4.00$

Postage Extra.

\section{HAYES SPRAYERS}

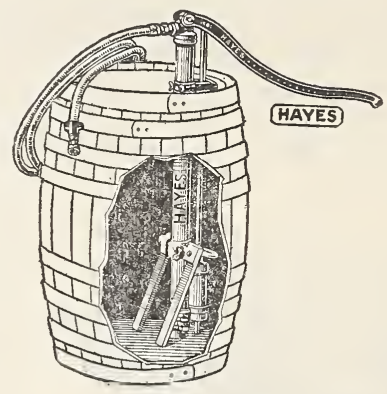

No. 172

\section{Hand Barrel Spray}

2 in. brass cylinder, $32 \times 2 \frac{1}{4} / 4$ in. air chamber, agitator with twin paddle which passes both sides of strainer and stirs the liquid thoroughly, bronze ball valves and seats, $12 \frac{1}{2} \mathrm{ft}$. of $1 / 2$-inch 5 ply hose and disc spray nozzle, without barrel.

1 in pkg., 36 lbs.

Each, $\$ 10.00$

Postage Extra.

\section{"Boss" Compressed Air}

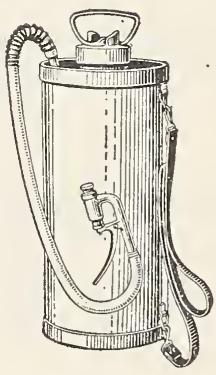

Capacity 4 gal., $17 \mathrm{t} / 4$ $\mathrm{x} 8$ in., heavy galvanized tank, fitted with patented nozzle which gives the spray a whirling motion, completely atomizing it into a solid mass of mist that covers evenly with no blank space in center, complete with $3 / 8$-in. hose.

1 in carton, 12 lbs.

Each $\$ 7.00$

Postage Extra.

Hayes Atomizers, No. 30

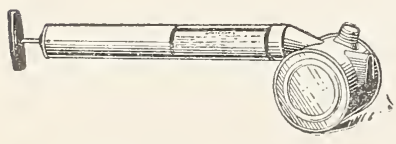

Small, compact, substantial and efficient. 2-inch can, one pint capacity. 10-inch length. Shipping weight 2 lbs.

No. 30

Price, 40c Each. Postage Extra.

Hayes Atomizers, No. 31

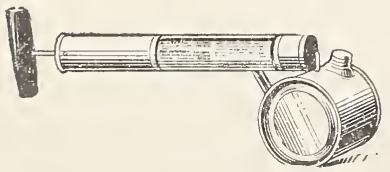

Strong, substantially constructed. Can 4inch diameter, capacity one quart. Length $14 \frac{1}{2}$ inches. Weight. 2 lbs.

No. 31

Price 50c Each.

Postage Extra.

\section{Hayes Atomizers, No. 33}

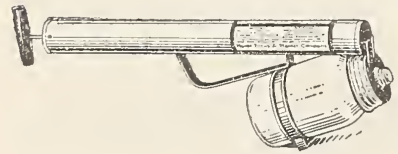

Standard quart Mason jar. Air chamber 13/4-inch diameter. 19-inch length. Coppered plunger rod, leather plunger with metal expander. Double tubes give large, dense spray. Shipping weight 3 pounds.

No. 33

Price $75 c$ Each.

Postage 'Extra. 


\section{HUDSON TROMBONE SPRAYER}

The Hudion Trombone Sprayer is a high pressure spray pump adapted for spraying orchards, vineyards, shrubbery, shade trees, potatoes and field crops; for whitewashing. disinfecting, spraying stock dip and fly oils, washing windows and automobiles, fighting fires and numerous other purposes.

It is double acting, maintaining a steady discharge without undue exertion on the part of the operator. All parts are brass, with bronze ball valves, easily accessible for cleaning etc Pump is dismantled by unscrewing packing nut and removing entire plunger.

May be used with a bucket, barrel or tank. Fitted with allpurpose nozzle, which produces any desired type of spray from a fine fog to a solid stream.

Standar Package-One in a heavy fiber carton. Shipping weight $b$ pounds.

Price \$4.50, Postage Haxtr:a.

We make specialties and defy anyone to furnish anything better. The seeds we buy are purchased from the very best growers in the United States and Europe. All that we ask is that you give us a trial order and you will find that you get more sceds for your money and they are just as good or better than rou can buy of any other seed house in America. Write us for prices on large orders.

\section{POSTAGE RATES BY PARCEL POST}

Parcel Post Matter moves very slowly and packages are some times lost in transit. If you wish insurance add $5 \mathrm{c}$ for each package of 70 pounds, in first, second and third zone. $50 \mathrm{lbs}$. is allowed in other zones.

Garden seeds priced by the packet, ounce, one-fourth pound, and one pound are postpaid. This does nut apply to beans, peas, corn, potatoes, implements, fertilizer, onion sets, grass and field seeds, they are not postpaid. In ordering these in one-pound lots add 10 cents per pound for postage and packing, and on larger quantities apply parcel post charges.

First and Second Zone, 150 miles

Third Zone, within 150 to 300 miles.

Fourth Zone. within 300 to 600 miles

\begin{tabular}{c||c}
$\begin{array}{c}\text { First } \\
\text { pound or } \\
\text { Fraction }\end{array}$ & $\begin{array}{c}\text { Each addi- } \\
\text { tional pound } \\
\text { or Fraction }\end{array}$ \\
\hline $\begin{array}{c}\text { or cents } \\
\text { s cents }\end{array}$ & $\begin{array}{c}1 \text { cent } \\
\text { a cents }\end{array}$ \\
$\begin{array}{l}1 \text { cents } \\
\text { cents }\end{array}$
\end{tabular}


อิจ (1)

\section{Carpenter Seed Co. \\ 76 University Ave., Provo, Utah}

\section{Annual Seed Book}

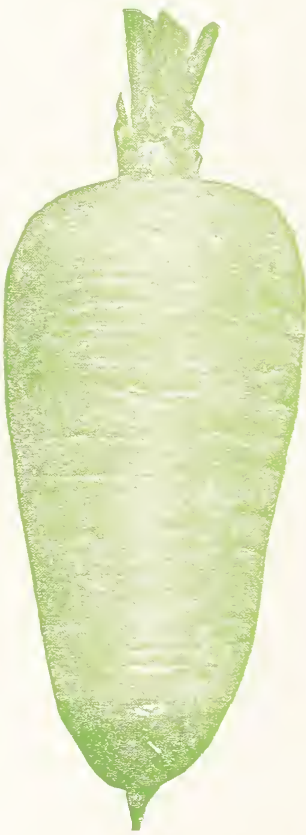

Tested Seeds of High Germination

Garden, Flower and Field

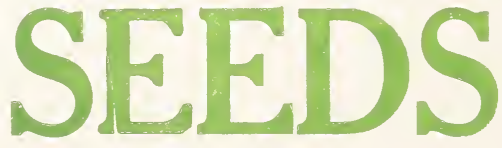

“OUR SEEDS GR OW" 